\title{
Identification of Binding Domains of the Growth Hormone-Releasing Hormone Receptor by Analysis of Mutant and Chimeric Receptor Proteins
}

\author{
Venita I. DeAlmeida and Kelly E. Mayo \\ Department of Biochemistry, Molecular Biology and Cell Biology \\ Northwestern University \\ Evanston, Illinois 60208
}

The hypothalamic peptide GH-releasing hormone (GHRH) stimulates the release of $\mathrm{GH}$ from the pituitary through binding and activation of the GHRH receptor, which belongs to the family of G proteincoupled receptors. The objective of this study was to identify regions of the receptor critical for interaction with the ligand by expressing and analyzing truncated and chimeric epitope-tagged GHRH receptors. Two truncated receptors, GHRH $\Delta \mathrm{N}$, in which part of the $\mathrm{N}$-terminal domain between the putative signal sequence and the first transmembrane domain was deleted, and $\mathrm{GHRH} \Delta \mathrm{C}$, which was truncated downstream of the first intracellular loop, were generated. Both the receptors were deficient in ligand binding, indicating that neither the $\mathrm{N}$-terminal extracellular domain ( $\mathbf{N}$ terminus) nor the membrane-spanning domains with the associated extracellular loops (C terminus) are alone sufficient for interaction with GHRH. In subsequent studies, chimeric proteins between the receptors for GHRH and vasoactive intestinal peptide (VIP) or secretin were generated, using the predicted start of the first transmembrane domain as the junction for the exchange of the $\mathbf{N}$ terminus between receptors. The chimeras having the $\mathbf{N}$ terminus of the GHRH receptor and the $C$ terminus of either the VIP or secretin receptor $\left(G_{N} V_{C}\right.$ and $\left.G_{N} S_{C}\right)$ did not bind GHRH or activate adenylate cyclase after GHRH treatment. The reciprocal chimeras having the $\mathbf{N}$ terminus of either the VIP or secretin receptors and the $\mathbf{C}$ terminus of the $\mathrm{GHRH}$ receptor $\left(\mathrm{V}_{\mathrm{N}} \mathrm{G}_{\mathrm{C}}\right.$ and $S_{N} G_{C}$ ) bound GHRH and stimulated cAMP accumulation after GHRH treatment. These results suggest that although the $\mathrm{N}$-terminal extracellular domain is essential for ligand binding, the transmembrane domains and associated extracellular loop regions of the GHRH receptor provide critical information necessary for specific interaction with GHRH. (Molecular Endocrinology 12: 750-765, 1998)

\section{INTRODUCTION}

$\mathrm{GH}$-releasing hormone ( $\mathrm{GHRH})$ is a peptide hormone secreted from the hypothalamus that stimulates the proliferation of pituitary somatotrophs and induces the synthesis and secretion of GH by these cells. Highaffinity binding of $\mathrm{GHRH}$ to its receptors on pituitary somatotrophs results in $\mathrm{G}$ protein coupling, adenylate cyclase activation and cAMP production, $\mathrm{Ca}^{2+}$ influx, increased expression of the $\mathrm{GH}$ gene, and enhanced $\mathrm{GH}$ secretion $(1,2)$. The $\mathrm{GHRH}$ receptors of several species have been cloned (3-6), and inactivating mutations in the receptor have been found in heritable $\mathrm{GH}$ deficiency diseases in both mice $(7,8)$ and humans $(9$, 10). Additionally, transcripts for alternatively spliced forms of the $\mathrm{GHRH}$ receptor truncated in the third intracellular loop have been found in patients with GH-producing pituitary tumors, although a role for these mutant receptors in tumorigenesis has not been established $(11,12)$.

The GHRH receptor is a $\mathrm{G}$ protein-coupled receptor (GPCR) with seven potential membrane-spanning domains and belongs to family $B$, group III (B-III) of the GPCR superfamily (13). It is highly homologous to the receptors for secretin (SEC) (14), vasoactive intestinal peptide (VIP) (15), pituitary adenylate cyclase-activating peptide (PACAP) (16), glucagon (17), glucagon-like peptide-1 (GLP-1) (18), and gastric inhibitory peptide (GIP) (19), which are also grouped in family B-III (13). These receptors are related to the receptors for $\mathrm{PTH}$ (20), PTH-related peptide (21), CRH (22), and calcitonin (23), which have a longer $\mathrm{N}$-terminal extracellular domain but share many common amino acids and a similar overall structure to the receptors of family B-III (24).

The receptors of family B-III have several conserved residues in the $\mathrm{N}$-terminal extracellular domain, includ- 
ing six cysteines, an aspartate, a tryptophan, and a glycine at positions corresponding to amino acids 60 , 65 , and 100 in the $\mathrm{GHRH}$ receptor (24). Mutation of the conserved cysteines in the VIP receptor (25), the aspartate in the $\operatorname{GHRH}(7,8,26)$, VIP (27), and glucagon (28) receptors, and the tryptophan or glycine in the VIP receptor (27) results in a loss of hormone binding and hormone-stimulated cAMP accumulation in cells expressing these mutant receptors. The $\mathrm{N}$-terminal domains of the receptors of this family are predicted to have a similar structure, presumably maintained by disulfide bonds between the conserved cysteines, and are thought to be involved in ligand binding (29). An $\alpha$-helical region within this $\mathrm{N}$-terminal domain is hypothesized to be involved in a coiled-coil interaction with an $\alpha$-helical region in the respective hormone (30), again suggesting a role for this domain in ligand binding.

The superfamily of GPCRs bind to, and are activated by, a diverse group of ligands ranging from ions and small peptides to large glycoproteins, and different receptors exhibit considerable variation in the structural determinants of ligand recognition (31-36). Ligand binding by several receptors in family $B$ has been studied using mutagenesis and chimeric receptor approaches. These studies reveal that the large N-terminal extracellular domains of the GLP-1 (37), VIP (38, 39 ), and PACAP (40) receptors are sufficient for low levels of specific ligand binding. However, other studies indicate that the presence of one or more extracellular loop regions and residues within the transmembrane domains is required for high-affinity ligand binding by the receptors for secretin, VIP, glucagon, calcitonin, PTH, GIP, and $\mathrm{CRH}(38,39,41-52)$, indicating that family $\mathrm{B}$ receptors are likely to exhibit multiple determinants of ligand interaction.

Other than the known importance of the conserved aspartate at position 60 , which is mutated in the little mouse, there is no information about the role of specific domains or residues of the $\mathrm{GHRH}$ receptor in ligand binding and signaling. As an initial step toward understanding the molecular mechanism of agonistdependent activation of the $\mathrm{GHRH}$ receptor, we designed experiments to identify domains of the GHRH receptor required for high-affinity $\mathrm{GHRH}$ binding. We generated two truncation mutants of the human $\mathrm{GHRH}$ receptor and four chimeras between the human $\mathrm{GHRH}$ receptor and the receptors for VIP or secretin and studied their ligand-binding and signaling properties.

\section{RESULTS}

\section{Generation and Analysis of Epitope-Tagged GHRH, VIP, and Secretin Receptors}

The analysis of mutant and chimeric receptors requires determination of the levels of receptor protein expressed and confirmation that the receptor is appropriately localized to the cell membrane. The amino acids encoding an influenza virus hemagglutinin (HA) epitope (YPYDVPDYA) were therefore introduced at the C-terminal ends of the wild-type GHRH, VIP, and secretin receptors, allowing detection of receptor protein using a monoclonal antibody against the epitope. In addition, the amino acids encoding the FLAG epitope (DYKDADDDK) were introduced in the $\mathrm{N}$ terminus of the wild-type GHRH receptor, downstream of the predicted signal peptide. A schematic representation of the $\mathrm{GHRH}$ receptor depicting the location of these epitope tags, as well as the boundaries of truncations and chimera junctions to be discussed subsequently, is shown in Fig. 1.

To ascertain whether the epitope tags affected receptor function, expression constructs for the wildtype and epitope-tagged receptors were transiently transfected into HeLa T4 cells, and the binding and signaling properties of the receptors were compared. Binding of GHRH to membranes of cells expressing the wild-type (GHRHR.wt), HA-tagged (GHRHR.HA), and FLAG-tagged (GHRHR.F) GHRH receptors was measured in competition assays (Fig. 2A), and it was observed that the membranes of cells expressing the wild-type and HA-tagged GHRH receptors showed a similar dose-dependent competition of GHRH binding, with $\mathrm{ED}_{50}$ values for competition of 5.2 and $3.2 \mathrm{~nm}$, respectively. In contrast, membranes of cells expressing the FLAG-tagged GHRH receptor construct did not bind GHRH. From Scatchard analysis of saturationbinding data, the apparent dissociation constants $\left(\mathrm{K}_{\mathrm{D}}\right)$ for $\mathrm{GHRH}$ binding by the wild-type and HA-tagged $\mathrm{GHRH}$ receptors were determined to be 36 and 31.6 $\mathrm{pM}$, respectively, with maximal binding $\left(\mathrm{B}_{\mathrm{MAX}}\right)$ values of 50.9 and $34.2 \mathrm{pmol} / \mathrm{mg}$ protein (data not shown). In response to $\mathrm{GHRH}$ stimulation, cells expressing the wild-type and HA-tagged forms of the GHRH receptor showed a similar dose-dependent accumulation of cAMP (Fig. 2B) with $\mathrm{ED}_{50}$ values of 5.7 and $4.4 \mathrm{~nm}$, respectively. Cells expressing the FLAG-tagged $\mathrm{GHRH}$ receptor did not accumulate cAMP, consistent with the inability of this receptor to bind $\mathrm{GHRH}$. Receptor constructs with the FLAG epitope tag were therefore used only for comparing the cellular localization of various receptor proteins in intact cells. In studies not shown, the presence of the C-terminal HA epitope tag was found not to affect the properties of the epitope-tagged VIP (VIPR.HA) and secretin (SECR.HA) receptors compared with their wildtype counterparts.

\section{Expression of Truncated GHRH Receptors}

For several GPCRs, it has been possible to broadly localize hormone-binding domains by expression and analysis of deletion constructs generated by the removal of large regions of the receptor protein. To determine whether either the $\mathrm{N}$ terminus or the $\mathrm{C}$ terminus of the GHRH receptor could bind ligand in the absence of the other domain, two truncation mutants were generated and transiently expressed in 


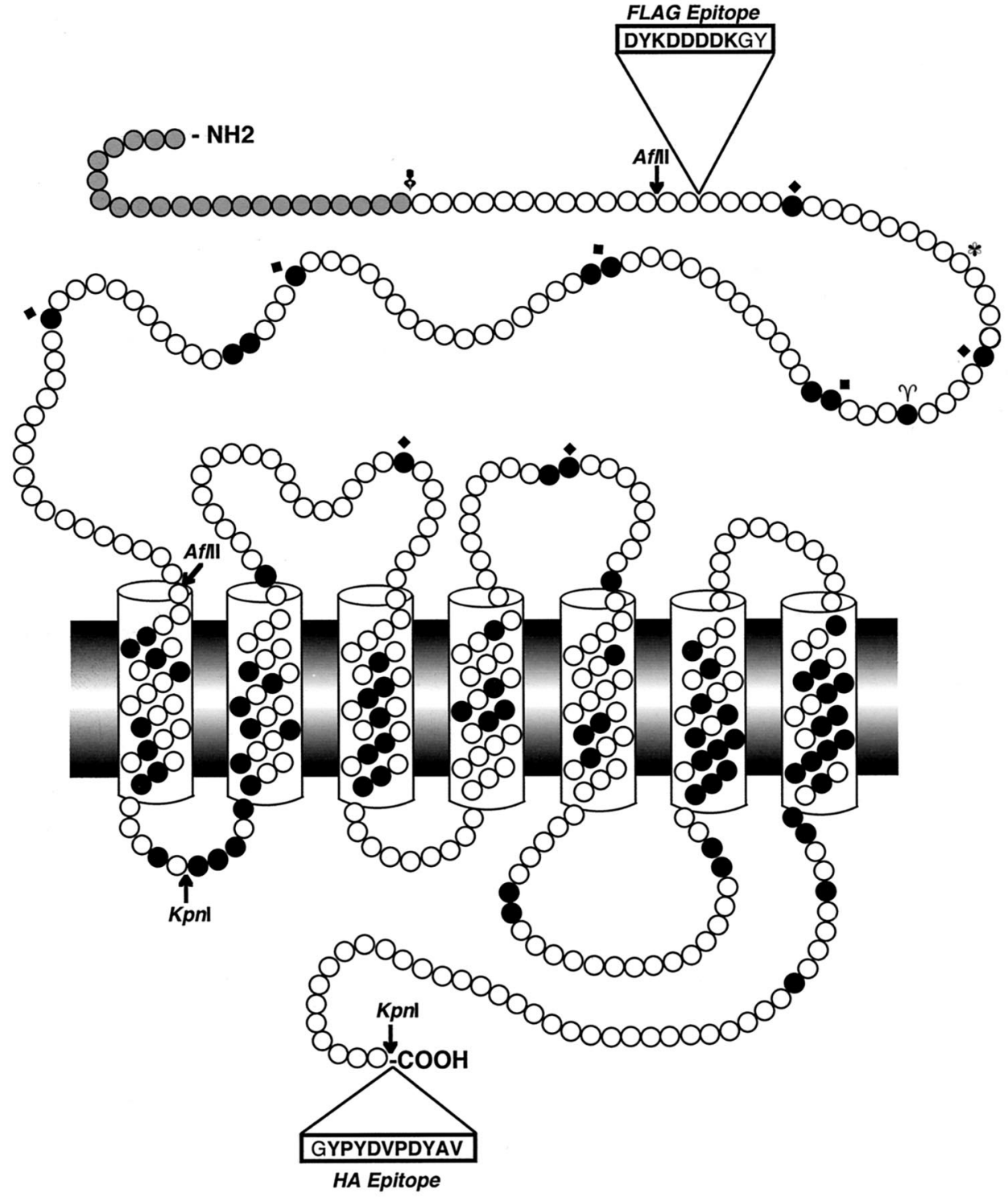

Fig. 1. Structure of the GHRH Receptor Showing the Location of Epitope Tags and Endpoints of the Truncated and Chimeric Mutant Receptors

The seven membrane-spanning domains are shown as cylinders crossing the lipid bilayer. The gray shaded circles represent the putative signal sequence, and the black shaded circles represent amino acids that are conserved in the related receptors for the hormones secretin, glucagon, GLP-1, GIP, VIP, and PACAP. The $(\infty)$ represents the putative signal-peptide cleavage site, the $(\%)$ represents the consensus site for $\mathrm{N}$-linked glycosylation, the $(\mathcal{V})$ represents aspartate residue 60 , which is mutated in the little mouse, and the $(\downarrow)$ represents the cysteines that are conserved within family B-III receptors. The location of the AfIII and $\mathrm{Kpnl}$ sites used to make truncations and fusions are indicated by arrows. The location and sequences of the FLAG and HA epitope-tags are also shown.

HeLa T4 cells. The amino acids between the signal peptide and the first transmembrane domain were deleted in the receptor $\mathrm{GHRH} \Delta \mathrm{N}$ by removing sequences between the two AfIII sites, and the amino acids downstream of the first intracellular loop were deleted in the receptor $\mathrm{GHRH} \Delta \mathrm{C}$ by removing sequences between the two Kpnl sites (Fig. 1). Immunoprecipitation of the metabolically labeled HA-tagged receptor proteins (Fig. 3A) shows that the two truncated receptors, $\mathrm{GHRH} \Delta \mathrm{N}$ and $\mathrm{GHRH} \Delta \mathrm{C}$, were expressed at or above levels of the full-length receptor. The apparent molecular masses were approximately $40 \mathrm{kDa}$ and $20 \mathrm{kDa}$, respectively; however, the immunoprecipitated protein from cells expressing $\mathrm{GHRH} \Delta \mathrm{N}$ showed the presence of two products, differing in size by $4 \mathrm{kDa}$. The cellular localization of the full-length and truncated epitope-tagged receptors was determined by immunofluorescence analysis using confocal microscopy with intact (for the FLAG-tagged receptors) or permeabilized (for the FLAG- and HA-tagged receptors) cells 
A

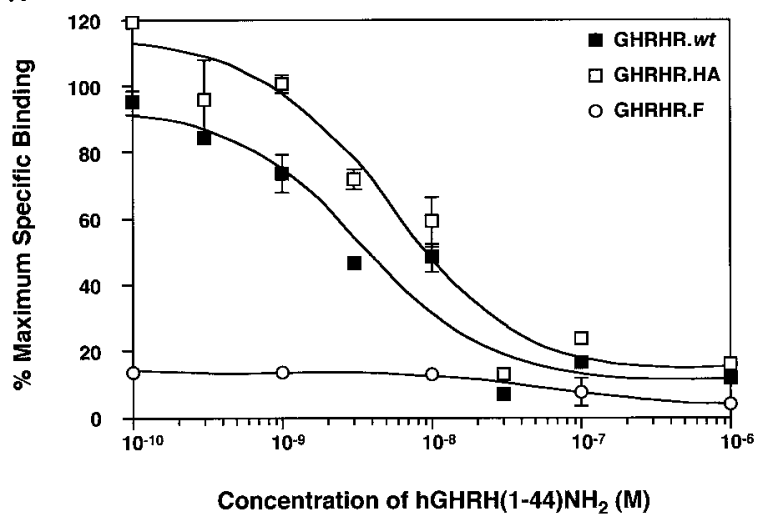

B

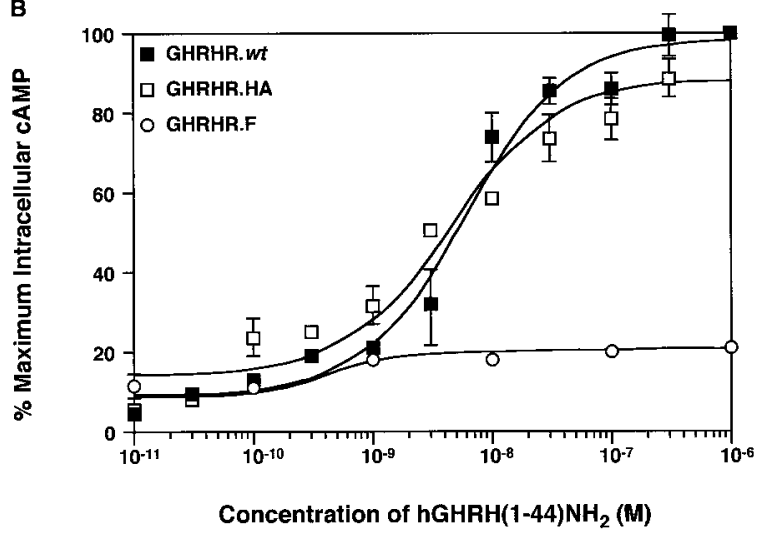

Fig. 2. Binding and Signaling Properties of Epitope-Tagged GHRH Receptors

A, Dose-dependent competition of GHRH binding to the wild-type and epitope-tagged GHRH receptors expressed in HeLa T4 cells. The relative amount of input radioligand bound in the presence of increasing concentrations of competitor is shown for each of the receptor constructs. The amount of GHRH bound in the absence of competitor corresponds to $8.2 \mathrm{pmol} /$ tube. B, Dose-dependent cAMP accumulation after GHRH treatment of HeLa T4 cells transfected with wild-type and epitope-tagged GHRH receptors. The relative amount of intracellular cAMP produced in response to increasing concentrations of hormone is shown for each of the receptor constructs. The amount of intracellular cAMP accumulated in cells treated with $1 \mu \mathrm{M}$ GHRH corresponds to $52 \mathrm{pmol} /$ well. Data points represent the mean of duplicate samples with the range of values indicated by the error bars; each panel is representative of at least two independent experiments.

(Fig. 3B). The full-length (GHRHR) and C-terminally truncated $(\mathrm{GHRH} \Delta \mathrm{C})$ receptors were localized similarly; receptor protein was distributed both on the cell surface and intracellularly, with the latter presumably representing receptor protein being transported to, or internalized from, the cell surface. For these two receptors, similar localization patterns were observed using antibodies against either the N-terminal FLAG tag or the C-terminal HA tag in permeabilized cells. In contrast, cells expressing the $\mathrm{N}$-terminally truncated receptor $(\mathrm{GHRH} \Delta \mathrm{N})$ appeared to accumulate protein preferentially in intracellular membranes, with a smaller proportion of the total receptor expressed on the cell surface. A perinuclear localization of this receptor protein was observed using both the FLAG and $\mathrm{HA}$ antibodies in permeabilized cells (Fig. 3B).

\section{Analysis of Truncated GHRH Receptors}

Binding of $\mathrm{GHRH}$ to membranes of HeLa T4 cells expressing the HA-tagged full-length or truncated forms of the GHRH receptor was measured in competition assays (Fig. 4A). The truncated receptors $\mathrm{GHRH} \Delta \mathrm{N}$ and $\mathrm{GHRH} \Delta \mathrm{C}$ did not bind $\mathrm{GHRH}$ when expressed by themselves or when coexpressed. In addition, neither truncated receptor decreased the ligand-binding ability of the full-length $\mathrm{GHRH}$ receptor when coexpressed with it. GHRH treatment did not stimulate cAMP accumulation in cells expressing the truncated receptor $\mathrm{GHRH} \Delta \mathrm{N}$, expressed either alone or together with the receptor GHRH $\Delta \mathrm{C}$ (Fig. 4B), consistent with the results of the binding studies. Coexpression of either GHRH $\Delta \mathrm{N}$ or GHRH$\Delta \mathrm{C}$ with the fulllength $\mathrm{GHRH}$ receptor did not diminish activation of adenylate cyclase by the full-length receptor (Fig. 4B).

The properties of the truncated $\mathrm{GHRH}$ receptors indicate that both the $\mathrm{N}$ terminus as well as the $\mathrm{C}$ terminus of the receptor are required for ligand binding and signaling. We therefore pursued an alternative approach to define the ligand-binding determinants of the GHRH receptor. Chimeras between related receptors have been used with great success in defining the ligand-binding domains of several receptors, such as those for the biogenic amines, glycoprotein hormones, and small peptides, and of several receptors of family $B$. We generated chimeras between the VIP or secretin receptors and the GHRH receptor and studied their ligand-binding and signaling properties to determine whether the $\mathrm{N}$ - or $\mathrm{C}$-terminal regions of the receptor were most critical for specific interaction with $\mathrm{GHRH}$.

\section{Expression of Chimeric GHRH and VIP or Secretin Receptors}

As described in Table 1, the chimeras between the GHRH and VIP or secretin receptors were generated by the exchange of the $\mathrm{N}$ termini of the HA-tagged receptors, with the fusions made at the AfIII site immediately before the first transmembrane domain. The $\mathrm{GHRH}-\mathrm{VIP}$ receptor chimeras were $\mathrm{G}_{N} \mathrm{~V}_{\mathrm{C}}$, which consists of the $\mathrm{N}$-terminal 127 residues of the $\mathrm{GHRH}$ receptor and residues 144-459 of the VIP receptor, and $V_{N} G_{C}$, generated by replacement of the 127 residues constituting the $\mathrm{N}$ terminus of the $\mathrm{GHRH}$ receptor with the equivalent 143 residues forming the $\mathrm{N}$ terminus of the VIP receptor. The GHRH-secretin receptor chimeras were $\mathrm{G}_{\mathrm{N}} \mathrm{S}_{\mathrm{C}}$, consisting of residues 1-127 of the GHRH receptor and residues 143-449 of the secretin receptor, and $\mathrm{S}_{N} \mathrm{G}_{\mathrm{C}}$, consisting of residues 1-142 of the secretin receptor and residues 128423 of the GHRH receptor. The expression of the wild-type and chimeric receptor proteins was as- 
A

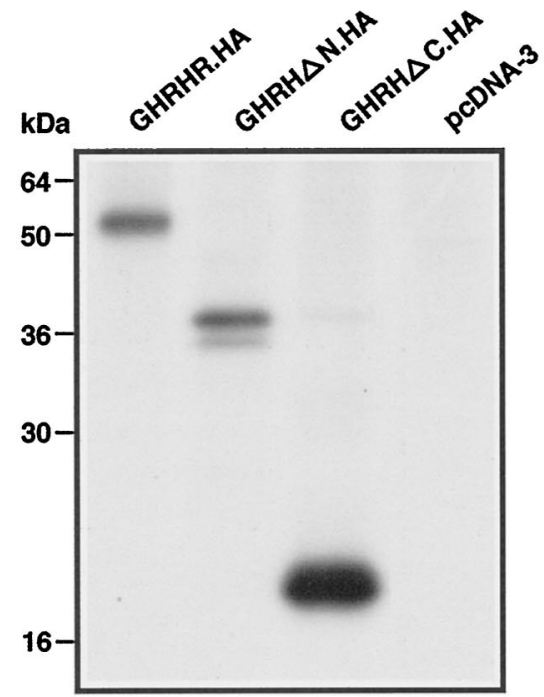

B GHRHR GHRH $\triangle N$ GHRH $\Delta C$ pcDNA-3

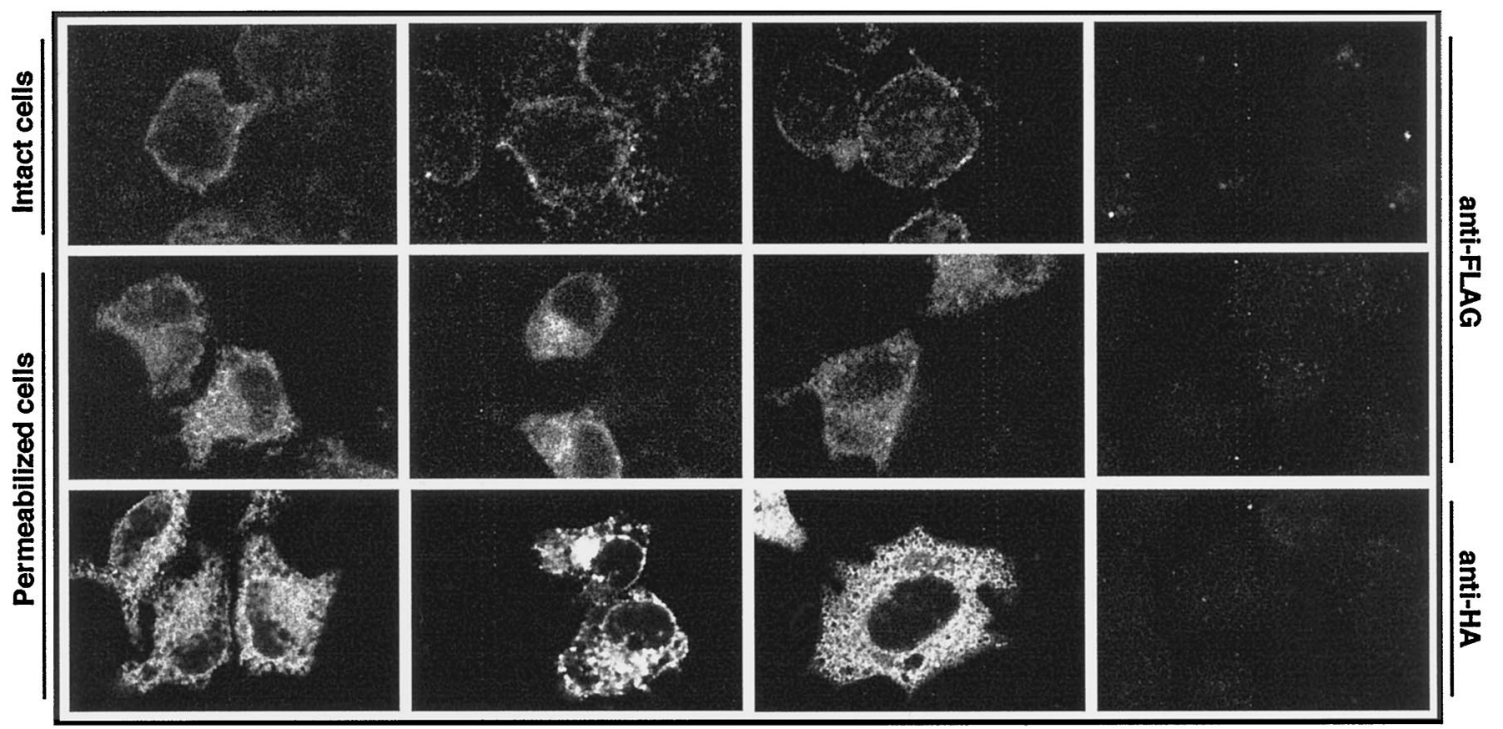

Fig. 3. Expression of Truncated GHRH Receptors

A, Immunoprecipitation of the HA-tagged wild-type and truncated human GHRH receptors. Equivalent amounts of metabolically labeled protein from HeLa T4 cells transfected with the indicated receptor constructs were immunoprecipitated using the monoclonal antibody 12CA5 against the HA-epitope and separated by SDS-PAGE on a $12 \%$ gel. The sizes of the mol wt standards included on the gel are shown on the left. B, Immunofluorescence localization of epitope-tagged wild-type and truncated human GHRH receptors. Indirect immunofluorescence of HeLa T4 cells transfected with pcDNA-3 or the indicated receptor constructs was performed using the anti-M2 monoclonal antibody against the FLAG-epitope (top and middle rows) or the 12CA5 antibody against the HA-epitope (bottom row). The panels in the top row are images of intact cells while those in the middle and bottom rows are images of cells permeabilized with $0.1 \%$ saponin. All slides were scanned using a confocal microscope under the same magnification and contrast settings for equivalent times, and the panels shown are representative of at least 20 fields observed in two independent experiments.

sessed by immunoprecipitation and, as shown in Fig. $5 \mathrm{~A}$, the proteins produced had the expected molecular sizes, and the chimeric receptors were expressed at levels comparable to, or above, those of the wild-type receptors. The chimeric receptors were glycosylated as determined by treatment with peptide-N-glycosidase $F$ (data not shown), which reduced the observed size of the receptor proteins in accord with the number of potential glycosylation sites in the $\mathrm{N}$-terminal extracellular domain of each (one in $G_{N} V_{C}$, three in $V_{N} G_{C}$, one in $G_{N} S_{C}$, and four in $S_{N} G_{C}$ ).

To confirm that the exchange of domains did not affect the cellular localization of the chimeric receptors, immunofluorescence analysis of permeabilized 
A

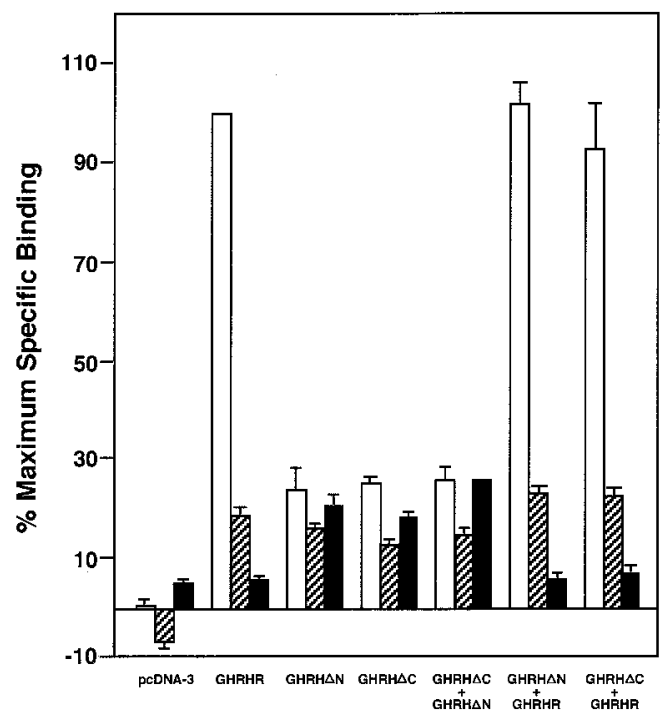

Concentration of hGHRH(1-44) $\mathrm{NH}_{2}$

None $\square \quad 1 \mathrm{nM} \quad \mathbb{Z} \quad 1 \mu \mathrm{M}$
B

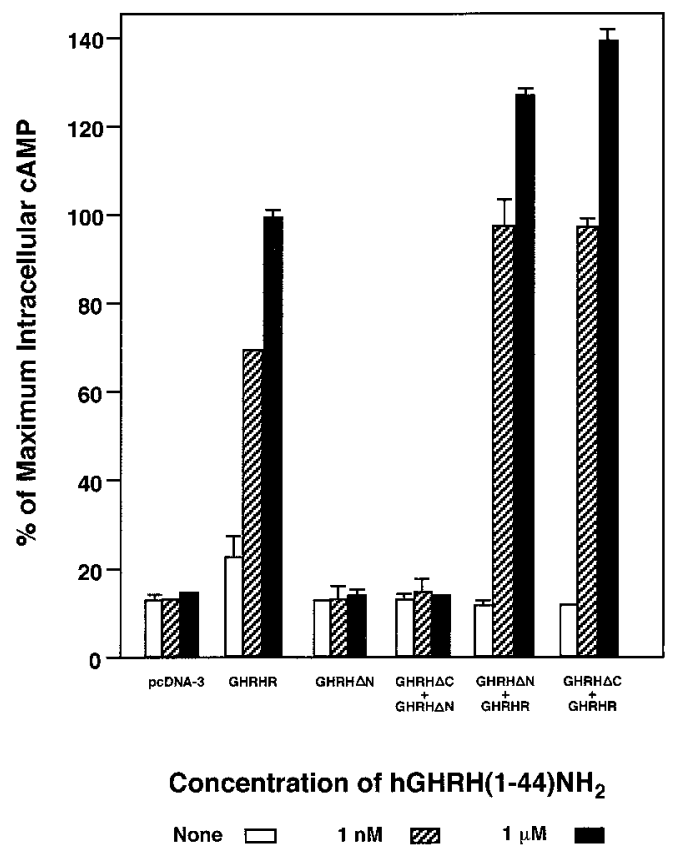

Fig. 4. Functional Analysis of Truncated GHRH Receptors

A, Binding of GHRH to membranes of cells expressing the wild-type and truncated human GHRH receptors. The relative amount of input radioligand bound in the absence and presence of two doses of unlabeled competitor is shown for each construct tested. The amount of GHRH bound in the absence of competitor corresponds to $6.7 \mathrm{pmol} / \mathrm{tube}$. B, Stimulation of intracellular cAMP levels by GHRH in HeLa T4 cells expressing the wild-type and truncated GHRH receptors. The relative amount of intracellular CAMP accumulated in response to two doses of GHRH is shown for each construct tested. The amount of intracellular cAMP accumulated in cells treated with $1 \mu \mathrm{M}$ GHRH corresponds to $80.2 \mathrm{pmol} /$ well. Data points represent the mean of duplicate samples with the range of values indicated by the error bars; each panel is representative of at least three independent experiments.

cells expressing the wild-type and chimeric receptors was performed, and the cells were observed using fluorescence microscopy. As seen in Fig. 5B, the wildtype and chimeric receptors are localized in a similar manner within the cell. All receptor proteins are distributed both on the cell surface and intracellularly, with the latter presumably representing receptor protein that is being transported to, or internalized from, the cell surface.

\section{Analysis of Chimeric GHRH and VIP Receptors}

The ligand-binding properties of the chimeras between the GHRH and VIP receptors were analyzed by measurement of binding to both ligands using competition assays (Fig. 6). The chimera $G_{N} V_{C}$ bound GHRH and VIP at extremely low levels, while the chimera $V_{N} G_{C}$ bound $\mathrm{GHRH}$ at levels comparable to membranes of cells expressing the wild-type $\mathrm{GHRH}$ receptor (Fig. 6A) but bound VIP at much lower levels than membranes of cells expressing the wild-type VIP receptor (Fig. 6B). Scatchard analysis of saturationbinding data for binding of GHRH and VIP to the chimera $V_{N} G_{C}$ was performed, and the $K_{D}$ values were determined to be $46 \mathrm{pm}$ and $156 \mathrm{pm}$, respectively. Dose-dependent accumulation of cAMP in cells trans- fected with the wild-type and chimeric receptors in response to treatment with GHRH and VIP is shown in Fig. 7. Cells expressing the chimera $G_{N} V_{C}$ show an increase in intracellular cAMP in response to $\mathrm{GHRH}$ and VIP only at high hormone concentrations $\left(>10^{-7} \mathrm{M}\right)$. However, cells expressing the chimera $V_{N} G_{C}$ showed a robust accumulation of cAMP in response to treatment with both GHRH and VIP, with $\mathrm{ED}_{50}$ values of 1.75 and $7.95 \mathrm{nM}$, respectively, consistent with the ability of this receptor to bind $\mathrm{GHRH}$, and more weakly, VIP. Interestingly, the chimera $V_{N} G_{C}$ mediates a much stronger cAMP response to $\mathrm{GHRH}$ than does the wild-type GHRH receptor, although the two receptors bound $\mathrm{GHRH}$ at comparable levels. The binding and signaling properties of the wild-type and chimeric GHRH and VIP receptors are summarized in Table 2.

\section{Analysis of Chimeric GHRH and Secretin Receptors}

The GHRH and VIP receptors are among the most homologous in family B-III. Although advantageous from the point of minimally disrupting structure, chimeras between these receptors might not fully reveal $\mathrm{GHRH}$ binding determinants if these determinants are 


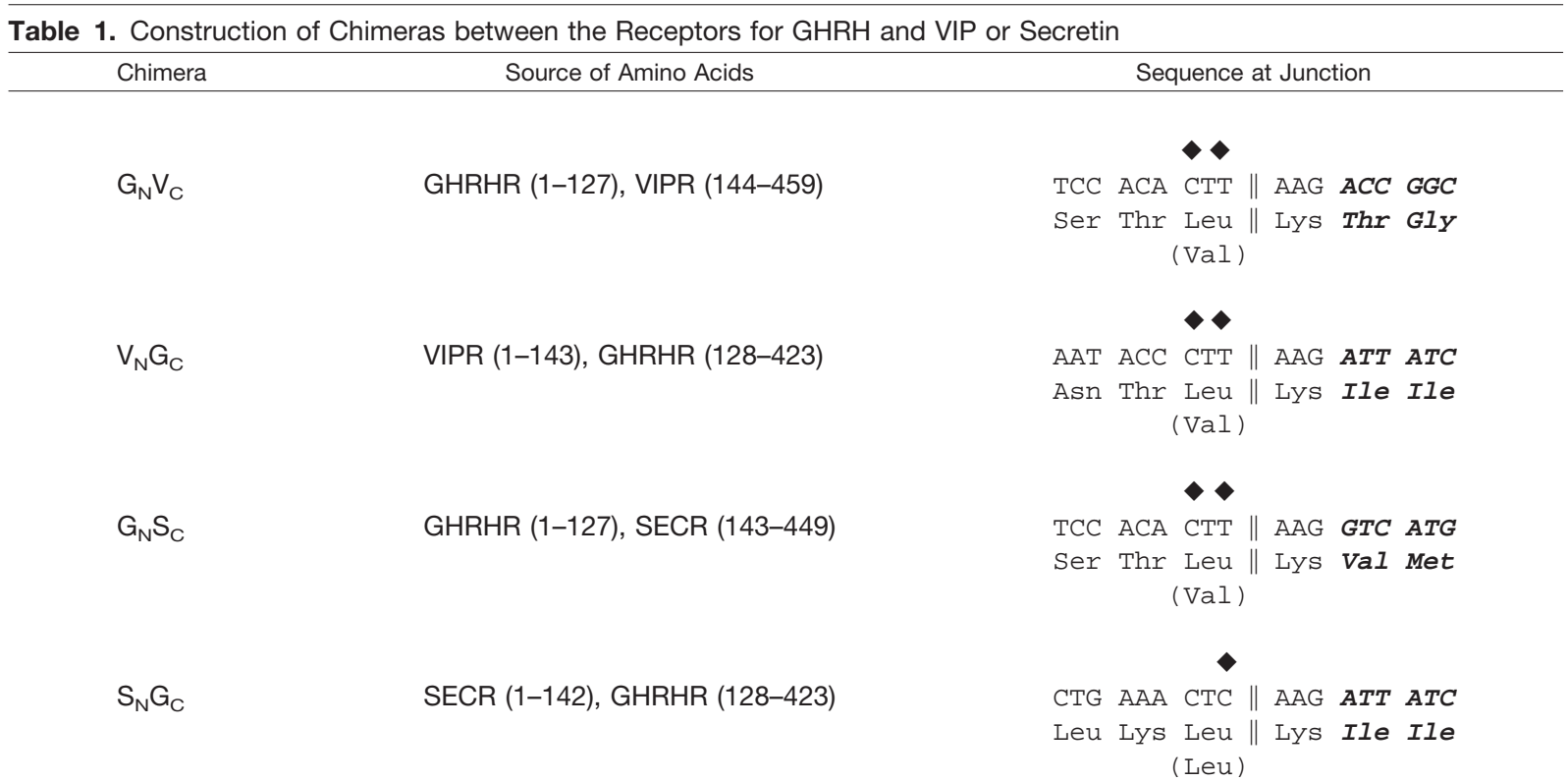

Denotes the nucleotides mutated by the generation of the Afll site, with the original amino acids shown in parentheses, and $\|$ denotes the chimera junction. The italic boldface residues are presumed to be in the first transmembrane domain of each of the chimeric receptors.

present in the analogous region of the VIP receptor. We therefore generated additional chimeras using the secretin receptor, which is less homologous than the VIP receptor to the GHRH receptor (35\% vs. 40\% identical) and which does not detectably bind $\mathrm{GHRH}$. The GHRH-binding ability of the two chimeras between the $\mathrm{GHRH}$ and secretin receptors was determined using binding competition assays (Fig. 8). The chimera $G_{N} S_{C}$ did not show any significant binding of $\mathrm{GHRH}$ while the reciprocal chimera $S_{N} G_{C}$ bound $\mathrm{GHRH}$ at lower levels than the wild-type GHRH receptor, although it was expressed at higher levels than the wild-type receptor. The $\mathrm{ED}_{50}$ for competition of $\mathrm{GHRH}$ binding by the chimera $S_{N} G_{C}$ was $1.15 \mathrm{~nm}$, and the $K_{D}$ value determined by Scatchard analysis of saturationbinding data was $259.3 \mathrm{pm}$. We were unable to iodinate secretin to high specific activity and therefore could not directly examine binding of secretin to these chimeras, but we studied the interaction of these chimeras with secretin by quantifying the intracellular cAMP levels in response to secretin stimulation. After treatment with $\mathrm{GHRH}$, adenylate cyclase was not activated in cells expressing the chimera $G_{N} S_{C}$. In contrast, cells expressing the reciprocal chimera $S_{N} G_{C}$ accumulated CAMP in a dose-dependent manner, although there was a small rightward shift in the response curve (Fig. 9A). Cells expressing either of the two chimeras $\mathrm{G}_{\mathrm{N}} \mathrm{S}_{\mathrm{C}}$ or $\mathrm{S}_{\mathrm{N}} \mathrm{G}_{\mathrm{C}}$ did not accumulate cAMP after treatment with secretin (Fig. 9B). The binding and signaling properties of the wild-type and chimeric GHRH and secretin receptors are summarized in Table 3.

\section{DISCUSSION}

GHRH and its receptor play an important role in the proliferation of pituitary somatotroph cells and the regulation of $\mathrm{GH}$ secretion (1, 2, 53), and high-affinity binding of $\mathrm{GHRH}$ by its receptor is a critical prerequisite for normal function of the $\mathrm{GH}$ axis (7-10). The molecular characterization of the association between $\mathrm{GHRH}$ and its receptor provides a framework for understanding their role in the regulation of $\mathrm{GH}$ secretion and growth, as well as their involvement in disorders of $\mathrm{GH}$ secretion. The approach we have taken toward this objective was to construct and analyze truncated and chimeric receptors, to begin to identify the extracellular domains of the GHRH receptor that are involved in its interaction with $\mathrm{GHRH}$. Our studies of truncated receptors led us to conclude that neither the $\mathrm{N}$-terminal extracellular domain nor the C-terminal domain, consisting of the transmembrane domains and the associated extracellular loops, can bind ligand in the absence of the other. The analysis of chimeras between the GHRH receptor and the receptors for VIP and secretin has revealed that although the $\mathrm{N}$ terminus is a critical domain for $\mathrm{GHRH}$ binding, the $\mathrm{N}$ terminus of a related receptor can be substituted, suggesting that the transmembrane domains and associated extracellular loops of the GHRH receptor form the key determinants for the specific binding of $\mathrm{GHRH}$.

Studies on the GHRH receptor of the little mouse, in which mutation of the conserved aspartate at position 60 results in a loss of the ability of the receptor to bind ligand (26) and activate adenylate cyclase $(7,8)$, provided the first indication that the integrity of the $\mathrm{N}$ 


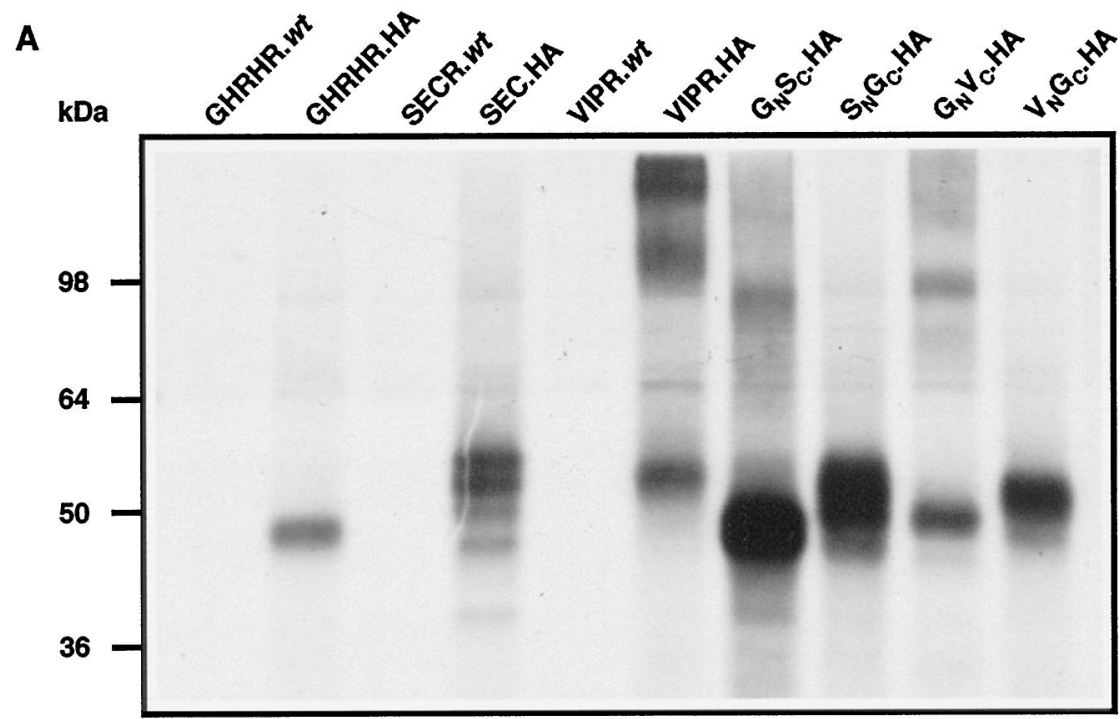

B

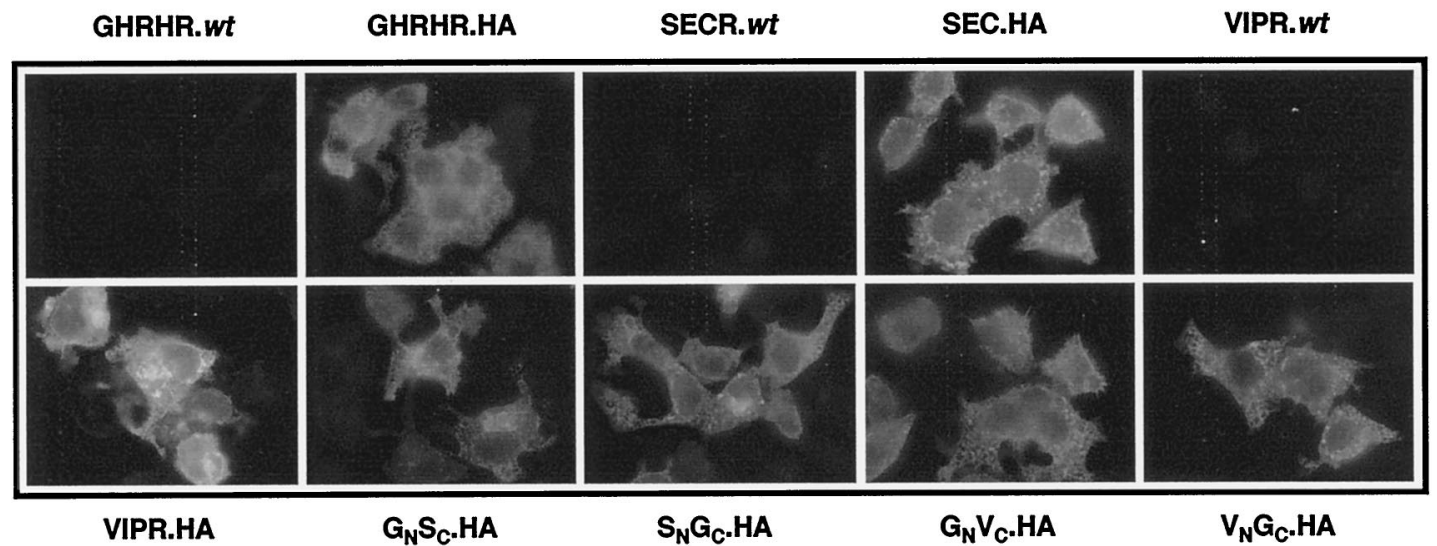

Fig. 5. Expression and Cellular Localization of Wild-Type and Chimeric GHRH Receptors

A, Immunoprecipitation of wild-type and chimeric HA-tagged GHRH, VIP, and secretin receptors. Equivalent amounts of protein from metabolically labeled HeLa T4 cells transfected with the various receptor constructs were immunoprecipitated and separated by SDS-PAGE on a 10\% gel. The sizes of the mol wt standards included on the gel are shown on the left. B, Immunofluorescence localization of HA-tagged wild-type and chimeric receptors in cells permeabilized with $0.1 \%$ saponin was performed, and the cells were observed by fluorescence microscopy. All slides were photographed using the same exposure times, and the panels shown are representative of at least 20 fields observed in two independent experiments. The monoclonal antibody 12CA5 against the HA epitope-tag was used for both immunoprecipitation and immunofluorescence analyses.

terminus of the GHRH receptor is essential for ligand binding. In this study, we found that the insertion of a FLAG epitope tag at position 37 in the $\mathrm{N}$ terminus of the receptor resulted in inactivation of the receptor. Although this effect could be due in part to altered expressed or localization of the FLAG-tagged receptor, our data are consistent with this insertion directly affecting the ligand-binding properties of the receptor. From computational structural studies on the receptors of family $\mathrm{B}$, it has been proposed that an $\alpha$-helical region in the $\mathrm{N}$ terminus of these receptors interacts with an $\alpha$-helical region in the $\mathrm{C}$ terminus of the bioactive region of the corresponding peptide hormone to form a coiled-coil motif (30). For the GHRH receptor, this $\alpha$-helical region is predicted to extend from resi- dues 26-40 and to interact with an $\alpha$-helix formed by residues 13-23 of the hormone. Inactivation of the receptor by the introduction of the FLAG epitope tag at position 37 might therefore result from the interruption of this $\alpha$-helical domain.

Deletion of the $\mathrm{N}$ terminus affected transport of the receptor $\mathrm{GHRH} \Delta \mathrm{N}$ to the cell surface and resulted in accumulation of the receptor protein in intracellular membranes, despite inclusion of the signal peptide in this construct. This abnormal localization of $\mathrm{GHRH} \Delta \mathrm{N}$ could be a consequence of the absence of the site for $\mathrm{N}$-linked glycosylation or of defective transport due to the proximity of the signal peptide and the first transmembrane domain. The larger of the two bands seen in immunoprecipitation analysis of extracts from cells 
A

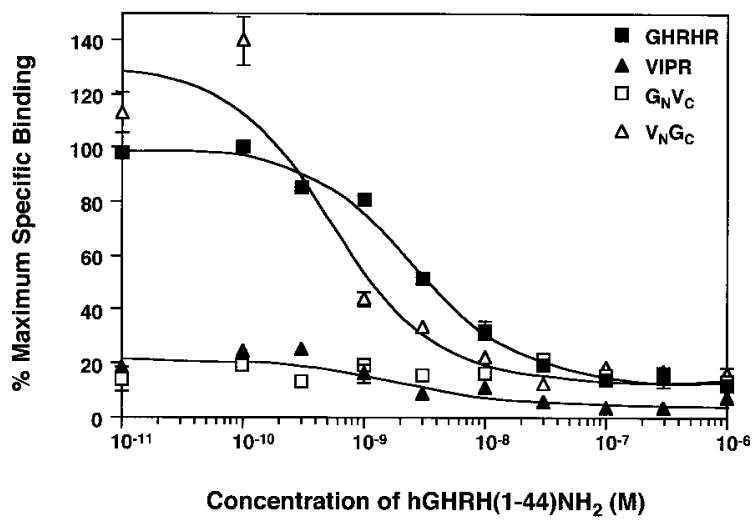

B

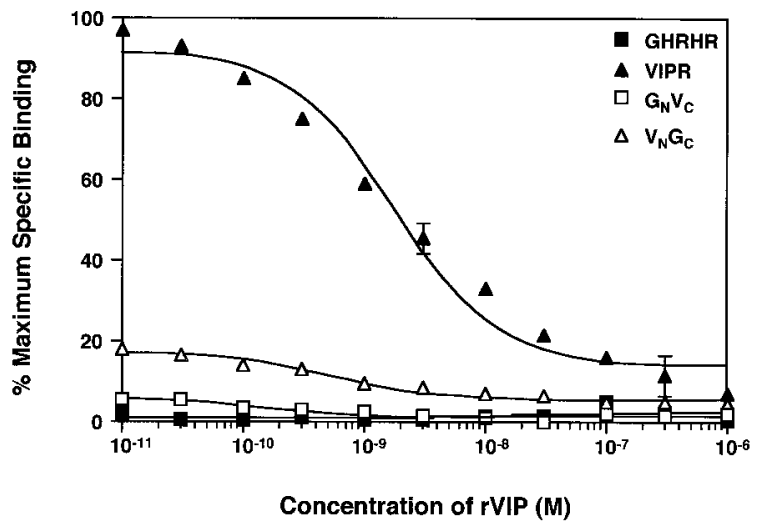

Fig. 6. Binding of GHRH and VIP to Wild-Type and Chimeric GHRH and VIP Receptors

Dose-dependent competition of GHRH (A) and VIP (B) binding to membranes of cells expressing the wild-type and chimeric GHRH and VIP receptors. The relative amount of input radioligand bound in the presence of increasing concentrations of the respective unlabeled competitor is shown for each construct tested. The amount of GHRH and VIP bound in the absence of competitor corresponds to 8.3 and $7.4 \mathrm{pmol} / \mathrm{tube}$, respectively. Data points represent the mean of duplicate samples with the range of values indicated by the error bars; each panel is representative of at least three independent experiments.

expressing $\mathrm{GHRH} \Delta \mathrm{N}$ is likely to be receptor protein in which cleavage of the signal peptide has not occurred, potentially due to structural constraints resulting from the adjacency of the first transmembrane domain. The receptor $\mathrm{GHRH} \Delta \mathrm{N}$ did not bind $\mathrm{GHRH}$ in a competition assay using total cell membranes, nor did it activate adenylate cyclase upon hormone treatment, implying that the $\mathrm{N}$ terminus is essential for $\mathrm{GHRH}$ binding. The deletion of the $\mathrm{N}$ termini of the receptors for VIP and glucagon also resulted in proteins that did not bind to their respective ligands $(27,48)$, suggesting that the $\mathrm{N}$ terminus plays an important role in the formation of the binding site of receptors of family B-III.

The receptor truncated in the first intracellular loop, $\mathrm{GHRH} \Delta \mathrm{C}$, was localized within cells in a manner similar to the wild-type $\mathrm{GHRH}$ receptor but did not bind
$\mathrm{GHRH}$, indicating that although essential for ligand binding, the $\mathrm{N}$ terminus alone is not sufficient for interaction with $\mathrm{GHRH}$. Our results with $\mathrm{GHRH} \Delta \mathrm{C}$ are similar to those obtained with a C-terminally truncated glucagon receptor (48) but are distinct from those obtained with a similarly truncated PACAP receptor that specifically bound PACAP, although with significantly lower affinity than the wild-type PACAP receptor (40).

Although coexpression of $\mathrm{N}$ - and C-terminal domains of receptors can result in partially functional receptors $(32,54,55)$, suggesting reconstitution of receptors by domain-domain interaction, coexpression of the two truncated forms of the GHRH receptor, $\mathrm{GHRH} \Delta \mathrm{N}$ and $\mathrm{GHRH} \Delta \mathrm{C}$, did not reconstitute ligand-

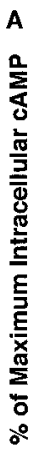

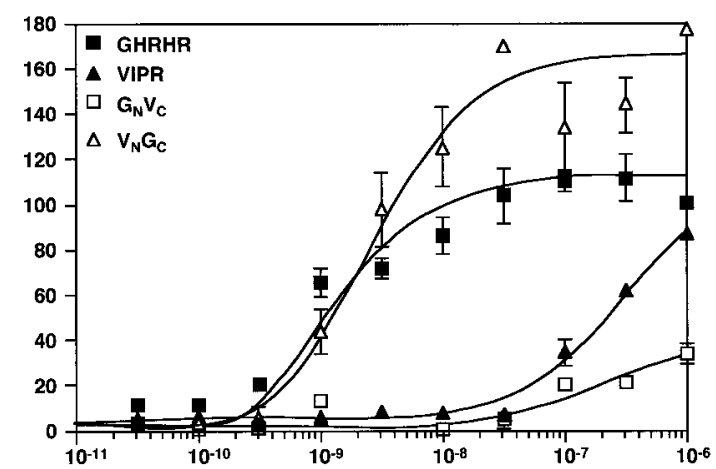

Concentration of hGHRH(1-44) $\mathrm{NH}_{2}$ (M)

B

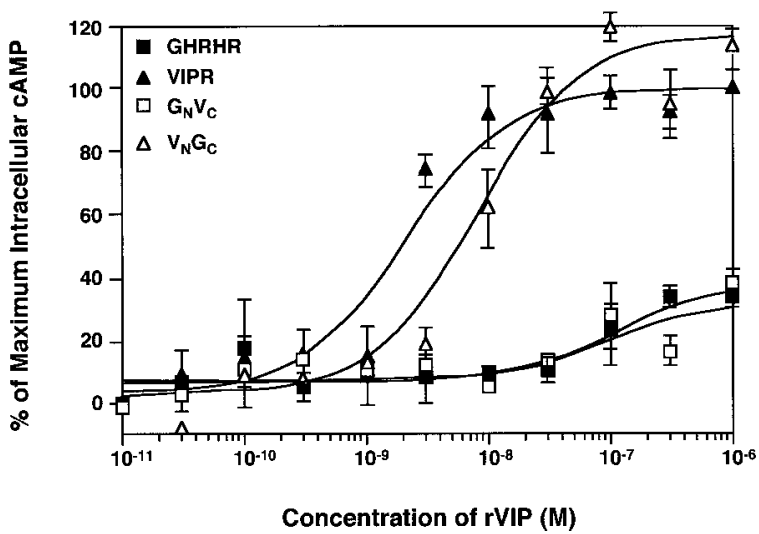

Fig. 7. Stimulation of cAMP Production by GHRH and VIP in Cells Expressing Wild-Type and Chimeric GHRH and VIP Receptors

Dose-dependent cAMP accumulation in HeLa T4 cells expressing wild-type and chimeric GHRH and VIP receptors after treatment with GHRH (A) and VIP (B). The relative amount of intracellular CAMP produced in response to increasing concentrations of hormone is shown for each construct tested. The amount of intracellular cAMP accumulated in cells treated with $1 \mu \mathrm{M} \mathrm{GHRH}$ and VIP corresponds to 280.4 and $229.8 \mathrm{pmol} / \mathrm{well}$, respectively. Data points represent the mean of duplicate samples with the range of values indicated by the error bars; each panel is representative of at least three independent experiments. 


\begin{tabular}{|c|c|c|c|c|}
\hline Property & GHRHR.HA & VIPR.HA & $\mathrm{G}_{\mathrm{N}} \mathrm{V}_{\mathrm{C}} \cdot \mathrm{HA}$ & $\mathrm{V}_{\mathrm{N}} \mathrm{G}_{\mathrm{C}} \cdot \mathrm{HA}$ \\
\hline GHRH binding, $\mathrm{ED}_{50}$ & $2.72 .9 \mathrm{~nm}$ & ns & ns & $0.5,0.7 \mathrm{~nm}$ \\
\hline GHRH binding, $\mathrm{K}_{\mathrm{D}}$ & $31.6,35.1 \mathrm{pm}$ & nd & nd & 46.1, $45.9 \mathrm{pm}$ \\
\hline GHRH binding, $B_{\text {MAX }}$ & $34.2,41.8$ & nd & nd & $63.8,56.4$ \\
\hline VIP binding, $\mathrm{ED}_{50}$ & ns & $1.8,1.9 \mathrm{~nm}$ & ns & $0.6,0.8 \mathrm{~nm}$ \\
\hline VIP binding, $\mathrm{K}_{\mathrm{D}}$ & nd & 143,149 рм & nd & $147,165 \mathrm{pm}$ \\
\hline VIP binding, $\mathrm{B}_{\mathrm{MAX}}$ & nd & $190.3,194.5$ & nd & $47.5,37.73$ \\
\hline GHRH cAMP response, $E_{50}$ & $1.2,1.4 \mathrm{nM}$ & $116,109 \mathrm{~nm}$ & $84,72 \mathrm{~nm}$ & $1.6,1.9 \mathrm{~nm}$ \\
\hline VIP cAMP response, $\mathrm{ED}_{50}$ & ns & $2.05,2.14 \mathrm{~nm}$ & $90.8,92.3 \mathrm{~nm}$ & $9.0,6.9 \mathrm{~nm}$ \\
\hline
\end{tabular}

The $\mathrm{ED}_{50}$ values for binding competition and CAMP accumulation were not calculated when the binding or signaling was not substantially different than background (denoted as ns), and saturation binding was not performed for receptors in which hormone binding over background was not observed in competition assays (indicated by nd). The two values shown represent the means of duplicate samples from two independent experiments. In the text, the average of these two independent determinations is used. $\mathrm{B}_{\text {MAX }}$ values are expressed as picomoles bound per mg protein.

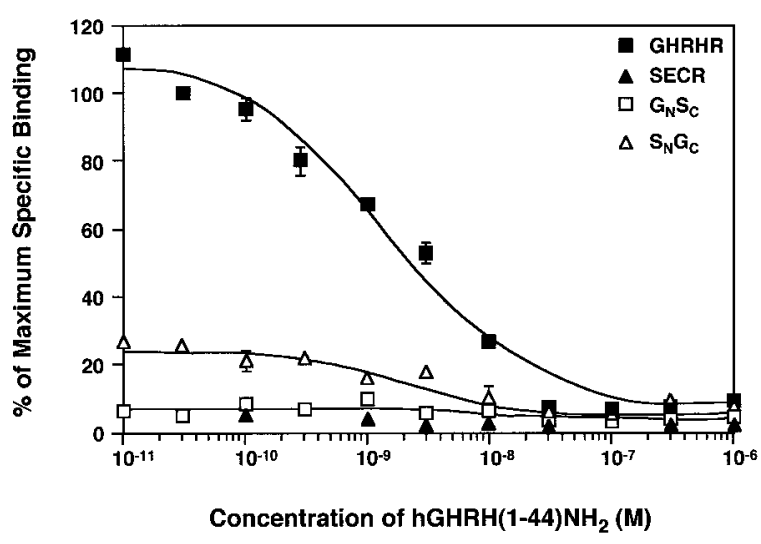

Fig. 8. GHRH Binding to Wild-Type and Chimeric GHRH and Secretin Receptors

Dose-dependent competition of GHRH binding to membranes of cells expressing the wild-type and chimeric GHRH and secretin receptors. The relative amount of input radioligand bound in the presence of increasing doses of unlabeled GHRH is shown for each construct tested. The amount of GHRH bound in the absence of competitor corresponds to $8.4 \mathrm{pmol} / \mathrm{tube}$. Data points represent the mean of duplicate samples with the range of values indicated by the error bars; each panel is representative of at least three independent experiments.

binding activity. This could be due to poor colocalization of the receptor fragments or due to a lack of interaction of the two truncated proteins resulting from disruption of the complex by the presence of the first transmembrane domain in both receptor fragments. Additionally, we coexpressed the truncated and wildtype GHRH receptors and found that there was no decrease in hormone binding or signaling by the wildtype receptor, implying that the truncated receptors $\mathrm{GHRH} \Delta \mathrm{N}$ and $\mathrm{GHRH} \Delta \mathrm{C}$ do not act as functional dominant negative mutants.

The generation of truncation constructs of GPCRs has been useful for the identification of structural domains involved in ligand binding in several receptors $(40,54-58)$. However, this approach has disadvan- tages, in that deletion of domains or truncations can result in structural alterations and mislocalization of the receptor proteins $(48,58)$. The generation of chimeras between two similar but distinct receptors can be used to correlate gain or loss of function with the exchanged domain, often with minimal effects on the structure of the receptor. Chimeric receptors generated by the exchange of homologous domains have proven useful in localizing the ligand-binding domains of receptors for biogenic amines $(31,32)$, glycoprotein hormones (33), and small peptides (34-36), and also of several receptors in family B including the VIP, secretin, glucagon, GIP, GLP-1, CRH, and PTH receptors (38, 39, 44, 46, 47, 49, 51, 52). We therefore applied this approach to characterize the ligand-binding domains of the $\mathrm{GHRH}$ receptor.

The wild-type GHRH, VIP, and secretin receptors show a high degree of specificity in their interaction with their respective ligands, although some ability of GHRH to activate the VIP receptor and of VIP to activate the $\mathrm{GHRH}$ receptor at high ligand concentrations has been observed $(3,59)$. Both the VIP and secretin receptors require the $\mathrm{N}$-terminal extracellular domain as well as the first extracellular loop for high-affinity ligand recognition $(29,38,39,41-44)$. Exchange of the $\mathrm{N}$-terminus of the VIP or secretin receptors with the corresponding region of the $\mathrm{GHRH}$ receptor resulted in chimeras $G_{N} V_{C}$, which showed a very weak response to both GHRH and VIP, and $G_{N} S_{C}$, which was unresponsive to both $\mathrm{GHRH}$ and secretin, consistent with studies of chimeras between the VIP and secretin receptors $(38,39)$. However, the chimeric receptors $V_{N} G_{C}$ and $S_{N} G_{C}$, having the $N$ terminus of the VIP or secretin receptors and the $\mathrm{C}$ terminus of the $\mathrm{GHRH}$ receptor, bound $\mathrm{GHRH}$ and stimulated adenylate cyclase in a dose-dependent manner in response to $\mathrm{GHRH}$. The chimera $S_{N} G_{C}$ bound $\mathrm{GHRH}$ at lower levels but had a similar cAMP response compared with the wild-type receptor, while the chimera $V_{N} G_{C}$ showed similar binding but a higher signaling response to $\mathrm{GHRH}$ than the wild-type receptor. Our observation that the chimera $V_{N} G_{C}$ bound VIP and 


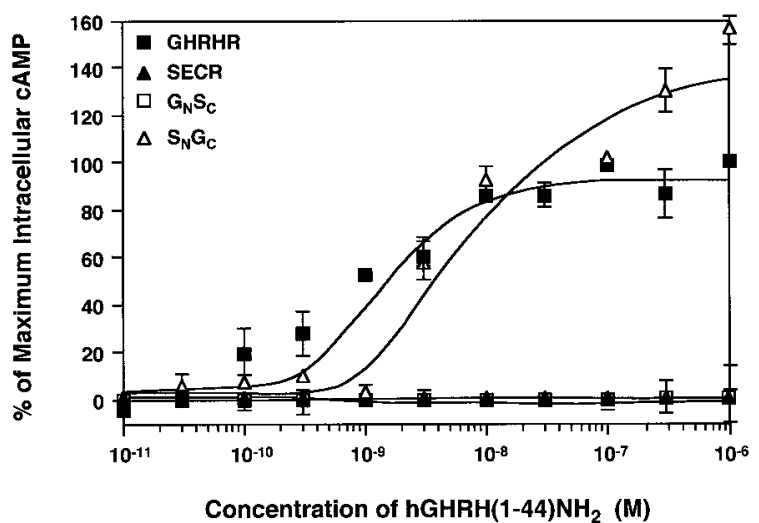

B

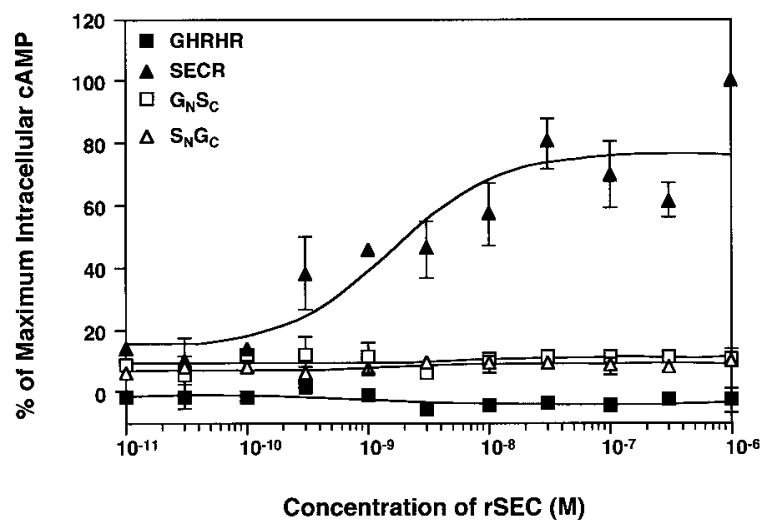

Fig. 9. Stimulation of cAMP Production by GHRH and Secretin in Cells Expressing Wild-Type and Chimeric Human GHRH and Secretin Receptors

Dose-dependent cAMP accumulation in HeLa T4 cells expressing the wild-type and chimeric GHRH and secretin receptors after treatment with GHRH (A) and secretin (B). The relative amount of intracellular CAMP produced in response to increasing amounts of the hormones is shown for each construct tested. The amount of intracellular cAMP accumulated in cells treated with $1 \mu \mathrm{M} \mathrm{GHRH}$ and secretin corresponds to 348.3 and $187 \mathrm{pmol} / \mathrm{well}$, respectively. Data points represent the mean of duplicate samples with the range of values indicated by the error bars; each panel is representative of at least three independent experiments.

activated adenylate cyclase in response to VIP can be explained by the fact that the aspartate residue at position 196 in the first extracellular loop of the VIP receptor, which is predicted to be important in interaction with VIP (43), is also present in the corresponding region of the GHRH receptor. The VIP receptor and the chimeric receptor $\mathrm{G}_{\mathrm{N}} \mathrm{V}_{\mathrm{C}}$ mediate cAMP accumulation in response to very high concentrations of $\mathrm{GHRH}$, consistent with a low-affinity interaction of the VIP receptor with GHRH. The differences between the binding and signaling responses in the chimeric receptors $S_{N} G_{C}$ and $V_{N} G_{C}$ suggest that some of the determinants required for $\mathrm{GHRH}$ binding are present in the $\mathrm{N}$ terminus of the VIP receptor but not the secretin receptor. Alignment of the $\mathrm{N}$-terminal regions of the three receptors $(3,24)$ indicates that among the residues predicted to form the $\alpha$-helix suggested to be involved in the coiled-coil interaction with the ligand (30), there is a higher homology between the GHRH and VIP receptors than between the GHRH and secretin receptors. Additionally, comparison of the amino acids at positions 13-23 in the hormones $\mathrm{GHRH}, \mathrm{VIP}$, and secretin, which are predicted to form the $\alpha$-helices that interact with the receptors (30), shows that this region of GHRH is more homologous to VIP than to secretin. These differences between VIP and secretin, and between their receptors, are likely to account for the differences in the $\mathrm{GHRH}$-binding and signaling responses of the chimeras $V_{N} G_{C}$ and $S_{N} G_{C}$.

Our data from the truncated receptors demonstrate that neither the $\mathrm{N}$ terminus nor the $\mathrm{C}$ terminus of the $\mathrm{GHRH}$ receptor can bind ligand in the absence of the other domain. Our studies of the chimeric receptors suggest that one or more of the extracellular loops, in conjunction with residues in the transmembrane domains, function as the determinants of binding specificity and activation for the GHRH receptor. Although the $\mathrm{N}$ terminus is essential for ligand binding, substitution of this domain with the corresponding domain of a related family B-III receptor reconstitutes functional $\mathrm{GHRH}$ binding. It has been hypothesized that all the receptors in this family have a similar structure in the $\mathrm{N}$-terminal domain as a result of the conserved pattern of cysteine residues forming conserved disulfide linkages (29), and an $\alpha$-helix in this region is predicted to be involved in the primary interaction with the ligand (30). From our results and those obtained from studies on other receptors in this family $(38-47,49-52,60)$, it is conceivable that the $\mathrm{N}$ terminus of these receptors plays a primary structural role in the initial interaction with the ligand, while residues in the extracellular loops and the transmembrane domains are involved in secondary interactions with the ligand that determine the specificity of ligand binding. Our results provide a basis for future studies to identify specific receptor domains and residues involved in recognition and binding of $\mathrm{GHRH}$. Chimeras in which individual extracellular loops of the receptor are substituted will enable the localization of binding determinants in a more precise manner, allowing site-directed mutagenesis to be used to define the key residues involved in specific ligand interaction. Identification of domains that are structurally important for the interaction of GHRH with its receptor will facilitate the design of specific receptor agonists and antagonists that might have therapeutic use in the diagnosis or treatment of diseases of the $\mathrm{GH}$ axis.

\section{MATERIALS AND METHODS}

\section{Plasmids, Receptor Constructs, and Hormones}

All receptor constructs were made in the vector pcDNA-3 (Invitrogen, Carlsbad, CA) downstream of the T7 polymerase 
Table 3. Binding and Signaling Properties of the GHRH-Secretin Wild-Type and Chimeric Receptors

\begin{tabular}{lcccc}
\hline \multicolumn{1}{c}{ Property } & GHRHR.HA & SECR.HA & $\mathrm{G}_{\mathrm{N}} \mathrm{S}_{\mathrm{C}} \cdot \mathrm{HA}$ & $\mathrm{S}_{\mathrm{N}} \mathrm{G}_{\mathrm{C}} \cdot \mathrm{HA}$ \\
\hline GHRH binding, $\mathrm{ED}_{50}$ & $1.8,2.1 \mathrm{nM}$ & $\mathrm{ns}$ & $\mathrm{ns}$ & $1.1,1.2 \mathrm{nM}$ \\
GHRH binding, $\mathrm{K}_{\mathrm{D}}$ & $31.6,35.1 \mathrm{pM}$ & $\mathrm{nd}$ & $\mathrm{nd}$ & $234.8,283.9 \mathrm{pM}$ \\
GHRH binding, $\mathrm{B}_{\mathrm{MAX}}$ & $34.2,41.8$ & $\mathrm{nd}$ & $\mathrm{nd}$ & $23.9,29.2$ \\
GHRH cAMP response, $\mathrm{ED}_{50}$ & $1.5,1.4 \mathrm{nM}$ & $\mathrm{ns}$ & $\mathrm{ns}$ & $5.5 \mathrm{nM}$ \\
Secretin cAMP response, $\mathrm{ED}_{50}$ & $\mathrm{~ns}$ & $1.55 \mathrm{nM}$ & $\mathrm{ns}$ & $\mathrm{ns}$ \\
\hline
\end{tabular}

The $\mathrm{ED}_{50}$ values for binding-competition and $\mathrm{CAMP}$ accumulation were not calculated when the binding or signaling was not substantially different than background (denoted as ns), and saturation binding was not performed for receptors in which hormone binding over background was not observed in competition assays (indicated by nd). The two values shown represent the means of duplicate samples from two independent experiments. In the text, the average of these two independent determinations is used. $\mathrm{B}_{\mathrm{MAX}}$ values are expressed as picomoles bound per $\mathrm{mg}$ protein.

promoter and were flanked by Hindlll and Xbal sites at the 5'and $3^{\prime}$-ends, respectively. Their sequences were confirmed using the dideoxy nucleotide chain termination method (Amersham Life Sciences, Arlington Heights, IL). In the numbering system used for all clones in subsequent sections, the first nucleotide of the initiation codon is defined as position 1 . The cDNA clones for the rat VIP (15) and secretin receptors (14) were provided by Dr. S. Nagata (Osaka Bioscience Institute, Osaka, Japan), and the cDNA for the human GHRH receptor was previously cloned in the laboratory (3). Peptide hormones were obtained from Peptides International (Louisville, $\mathrm{KY}$ ) or Peninsula Laboratories (Belmont, $\mathrm{CA}$ ).

\section{Generation of Epitope-Tagged Receptor Constructs}

Oligonucleotides having 20-22 nucleotides complementary to the C-terminal end of the GHRH, VIP, or secretin receptors and encoding the influenza virus HA epitope (61) were synthesized. Recognition sites for the enzymes Kpnl and Xbal were engineered on either side of the HA epitope with the stop codon within the Xbal site. These primers, together with upstream primers within each of the receptor cDNAs, were used to amplify the C-terminal fragment of each receptor. The PCR products were cloned in context with the respective receptor into the expression vector pcDNA-3 to generate full-length clones for the epitope-tagged receptors (GHRHR.HA, VIPR.HA, and SECR.HA).

The amino acids for the FLAG epitope tag (62) were inserted at the N-terminal domain of the GHRH receptor downstream of the putative signal peptide at residue 37 using gene splicing by overlap extension (63). An oligonucleotide primer encoding the FLAG epitope tag with a site for the enzyme EcoRV, $3^{\prime}$ of the tag and having 22 nucleotides complementary to the GHRH receptor was synthesized. This primer and a downstream primer were used to amplify a fragment corresponding to amino acids $130-580$ of the receptor. A primer complementary to the sense primer for the FLAG epitope and the T7 promoter primer were used to amplify a fragment corresponding to amino acids $1-140$ of the receptor. The two fragments were annealed and amplified using the two external primers, and the product was cloned in context with the $\mathrm{C}$-terminal region of the receptor to generate the FLAGtagged GHRH receptor GHRHR.F.

\section{Generation of Truncation and Chimeric Constructs of the GHRH Receptor}

Using site-directed mutagenesis (64), the recognition site for the enzyme AfIII (CTTAAG) was engineered in the tagged GHRH receptors as shown in Fig. 1. The site was introduced at nucleotides 100-106 and 385-390 (corresponding to amino acids 34-35 and 129-130), respectively, in the HAtagged receptor and at nucleotides 385-390 in the FLAGtagged receptor. This resulted in changes in amino acids 35 and 129 (Arg to Lys and Val to Leu, respectively).
Removal of the 285-bp AfIII-AfIII fragment resulted in the deletion of the extracellular domain between amino acids 35 and 129 to give the N-terminally truncated HA-tagged construct $(\mathrm{GHRH} \triangle \mathrm{N}$.HA). Deletion of the 278-bp EcoRV-AfIII fragment of the FLAG-tagged GHRH receptor, followed by filling-in with Klenow polymerase and ligation, generated the $\mathrm{N}$-terminally truncated FLAG-tagged construct (GHRH $\Delta$ N.F).

An oligonucleotide complementary to the first intracellular loop of the GHRH receptor and with nucleotides 467-472 altered to form a recognition site for the enzyme Kpnl, together with the $\mathrm{T} 7$ promoter primer, was used to amplify a 480-bp N-terminal fragment of the GHRH receptor. The PCR product was digested with HindIII and Kpnl and ligated with the large fragment obtained by digestion of the full-length HA-tagged GHRH receptor with the same enzymes, to generate the construct GHRH $\Delta \mathrm{C} . \mathrm{HA}$, truncated within the first intracellular loop. The same primers were used to amplify a 516-bp fragment using the FLAG-tagged GHRH receptor as a template, and the product was ligated into pcDNA-3 to generate the clone GHRH $\Delta$ C.F.

The chimeras were constructed by the exchange of $\mathrm{N}$ terminal extracellular domains between the HA-tagged receptors with the predicted start of the first transmembrane domain of the receptors as the junction (Table 1). The recognition site for $A$ flll was engineered at nucleotide positions 385-390, 427-432, and 424-439 (amino acids 129-130, 143144, and 142-143) in the cDNAs for the GHRH, VIP, and secretin receptors, respectively, and the wild-type receptors having the epitope tag and $A f / I$ site were used for all subsequent studies. The $\mathrm{N}$-terminal fragments that were exchanged between the receptors were generated by digestion of the cDNAs for the wild-type receptors with HindIII and AfIII.

\section{Expression of Receptor Constructs in HeLa T4 cells Using the Vaccinia-T7 RNA Polymerase Hybrid Expression System}

All experiments were performed using cells transfected with various receptor constructs using the Vaccinia Virus-T7 polymerase hybrid expression system (65). Subconfluent monolayers of HeLa T4 cells cultured in DMEM (Sigma Chemical Co., St. Louis, MO) supplemented with 5\% FBS (GIBCO BRL, Grand Island, NY) were infected with Vaccinia virus vTF7.3 expressing the bacteriophage T7 RNA polymerase (obtained under license from Dr. Bernard Moss, NIH, Bethesda, MD), at a multiplicity of infection of 10 , for $30 \mathrm{~min}$ in PBS/0.1\% BSA. The various plasmid DNAs were incubated with liposomes (66) at the ratio of $4-5 \mu \mathrm{g}$ of lipid per $\mu \mathrm{g}$ DNA, in Opti-MEM I medium (GIBCO BRL), for 20-30 min at room temperature. Virus was aspirated from the cells, and the DNA/liposome mixture was added to the cells and incubated at $37 \mathrm{C}$ in 5\% $\mathrm{CO}_{2}$ for 15-16 h. The amount of DNA used for transfection varied with the size of the plates. 


\section{Metabolic Labeling of Transfected Cells and Immunoprecipitation of Epitope-Tagged Receptors}

Cells grown in 35-mm dishes and transfected with $5 \mu \mathrm{g}$ DNA per plate were starved in cysteine/methionine-deficient DMEM (ICN Biomedical Inc., Irvine, CA) for $30 \mathrm{~min}$ and labeled with $50 \mu \mathrm{Ci} /$ plate ProMix (Amersham) in the same medium for $2 \mathrm{~h}$ at $37 \mathrm{C}$ in $5 \% \mathrm{CO}_{2}$. The cells were washed with PBS, harvested, and subjected to one cycle of freezethaw. The cell pellets were resuspended in $400 \mu \mathrm{l}$ RIPA buffer [150 mm NaCl, $50 \mathrm{~mm}$ Tris-HCl ( $\mathrm{pH} 7.5$ ), 1\% Nonidet P-40, $0.5 \%$ deoxycholic acid, and $0.1 \%$ SDS] containing $0.1 \mathrm{~mm}$ phenylmethylsulfonyl fluoride and $1 \mu \mathrm{g} / \mathrm{ml}$ leupeptin, and the membranes were solubilized by incubation on ice for $1 \mathrm{~h}$ with vortexing. The lysate was clarified by centrifugation and incubated with $0.5 \mu \mathrm{g}$ of the HA-specific 12CA5 ascites fluid (a gift from Dr. Robert A. Lamb, Northwestern University) for 3-4 $\mathrm{h}$ at $4 \mathrm{C}$ on a hematology mixer. At the end of this period, 30 $\mu \mathrm{l}$ of a $50 \%$ suspension of protein A-Sepharose beads (Pharmacia, Piscataway, NJ) in PBS were added to the tubes, and the incubation was continued for $30 \mathrm{~min}$. The beads were washed four times with $500 \mu \mathrm{l}$ cold RIPA buffer and once with cold wash buffer ( $50 \mathrm{~mm}$ Tris- $\mathrm{HCl} / \mathrm{pH} 7.5,150 \mathrm{~mm} \mathrm{NaCl}, 5 \mathrm{~mm}$ EDTA) and resuspended in $30 \mu \mathrm{l}$ of $2 \times$ SDS-PAGE sample buffer (50 mM Tris-HCl/pH 6.8, 2\% SDS, 10\% glycerol, 5\% $\beta$-mercaptoethanol, $0.1 \%$ bromophenol blue). The samples were boiled for 5 min before separation by SDS-PAGE using a Tris-glycine buffer with See-Blue Pre-Stained Standard (NOVEX, San Diego, CA) as size markers. The gels were fixed in $20 \%$ methanol $/ 7 \%$ acetic acid, saturated with glacial acetic acid, impregnated with $22 \% \mathrm{wt} / \mathrm{vol}$ of 2,5-diphenyl-oxazole in acetic acid, dried, and exposed to Kodak X-OMAT AR film (Eastman Kodak Company, Rochester, NY). For glycosylation analysis, immunoprecipitated proteins were digested for $4 \mathrm{~h}$ at $37 \mathrm{C}$ with $0.2 \mathrm{U}$ of peptide- $\mathrm{N}$-glycosidase $\mathrm{F}$ (Boehringer Mannheim Corp., Indianapolis, IN) in a buffer containing $20 \mathrm{~mm} \mathrm{Na}_{2} \mathrm{HPO}_{4}$ (pH 8.0), $20 \mathrm{~mm}$ EDTA, 1\% NP40, $1 \mu \mathrm{g} / \mathrm{ml}$ leupeptin, $0.1 \mu \mathrm{g} / \mathrm{ml}$ pepstatin $\mathrm{A}$, and $1 \mu \mathrm{g} / \mathrm{ml}$ aprotinin.

\section{Immunofluorescence Localization of Epitope-Tagged Receptors}

HeLa T4 cells cultured on glass coverslips in $35-\mathrm{mm}$ plates were transfected as described. For permeabilized cells expressing the FLAG-tagged constructs, the coverslips were washed twice in PBS and incubated for $2 \mathrm{~h}$ at $4 \mathrm{C}$ with 3 $\mu \mathrm{g} / \mathrm{ml}$ of the anti-FLAG M2 monoclonal antibody (Kodak IBI, New Haven, CT) in PBS containing $0.1 \%$ saponin. After extensive washing, the coverslips were incubated at $4 \mathrm{C}$ for 30 min with $2 \mu \mathrm{g} / \mathrm{ml}$ of fluorescein isothiocyanate (FITC)-conjugated goat anti-mouse secondary antibody (Jackson ImmunoResearch Laboratories, West Grove, PA) in PBS containing $0.1 \%$ saponin and $0.2 \%$ whole goat serum, and after extensive washing with PBS, the coverslips were mounted in FITCGuard (Testog Inc., Chicago, IL). For nonpermeabilized cells, incubation was carried out under similar conditions using primary and secondary antibodies diluted in PBS (without saponin). For cells expressing the HA-tagged receptor constructs, the coverslips were washed twice in PBS, fixed with $1 \%(\mathrm{wt} / \mathrm{vol})$ paraformaldehyde in PBS for $10 \mathrm{~min}$, and immunofluorescense analysis was performed as described, using $1 \mu \mathrm{g} / \mathrm{ml}$ of the HA-specific 12CA5 ascites fluid. The images of cells expressing the FLAG-tagged and HA-tagged receptors in Fig. 3B were optical sections obtained using confocal laser scanning microscopy with a Bio-Rad MRC 600 (Bio-Rad Laboratories, Richmond, CA) connected to a Nikon microscope using a $40 \times$ objective. All samples were scanned under the same contrast settings for equivalent times, and optical sections were taken through the central plane of the cell. Photomicroscopy of cells expressing the wild-type and chimeric receptors in Fig. 5B was performed using a $63 \times$ objective on a Zeiss Axiophot microscope (Carl Zeiss Inc., Oberkochen, Germany) with equivalent exposure times.

\section{Measurement of Ligand Binding}

For binding assays, cells grown in 10-cm dishes were transfected with $10 \mu \mathrm{g}$ DNA per plate. Binding assays were performed using approximately $50 \mu \mathrm{g}$ of membrane protein per reaction, prepared from transfected cells as described (3). The reactions were carried out at $25 \mathrm{C}$ for $1 \mathrm{~h}$ in a $300-\mu$ l reaction volume and were terminated by centrifugation at $4 \mathrm{C}$ for $10 \mathrm{~min}$. The membrane pellets were washed once with binding buffer, and the amount of bound radioligand was measured using a $\gamma$-counter. The assays were performed with duplicate samples, and the means were used for all further calculations. For competition studies, the membrane proteins were incubated with either $\left(3-\left[{ }^{125}\right]\right]$ iodotyrosyl $\left.\left.\right|^{10}\right) \mathrm{GHRH}(1-44)$-amide or $\left(3-\left[{ }^{125}\right]\right.$ iodotyrosy $1{ }^{10}$ ) VIP present at a concentration of 70 pM (Amersham), in the absence or presence of increasing concentrations of the unlabeled hormone. The nonspecific binding, determined as the percent of input counts bound in the presence of $1 \mu \mathrm{M}$ unlabeled hormone, was approximately $13 \%$ and $7 \%$ for $\mathrm{GHRH}$ and VIP, respectively, and was subtracted from all raw data to give the specific bound counts. The percentage of the maximum specific bound counts for each data point was calculated using the specific counts bound by the wild-type receptor in the absence of competitor as $100 \%$. Saturation-binding assays are representative of at least two independent experiments. The concentration of the radioligand ranging from $1.37 \mathrm{pM}$ to $700 \mathrm{pM}$ and the corresponding unlabeled hormone was present at $1 \mu \mathrm{M}$. The binding-competition data were fit to a one-site competition equation to determine $\mathrm{ED}_{50}$, and Scatchard analysis of saturation-binding data was used to determine $\mathrm{K}_{\mathrm{D}}$ and $\mathrm{B}_{\mathrm{MAX}}$ values using the program GraphPad Prism (GraphPad Software Inc., San Diego, CA).

\section{Measurement of Intracellular cAMP Levels}

For the measurement of cAMP responses, cells were transfected in 12-well plates using $2.5 \mu \mathrm{g}$ plasmid DNA per well. The cells were treated with hormones as described (3) for 20 min at $37 \mathrm{C}$, lysed in $150 \mu \mathrm{l}$ of cold $0.1 \mathrm{M} \mathrm{HCl}$, and harvested, and the lysates were neutralized with an equal volume of 150 $\mathrm{mm}$ Tris- $\mathrm{HCl}(\mathrm{pH}$ 8) containing $4 \mathrm{~mm}$ EDTA. The protein was removed by centrifugation for $10 \mathrm{~min}$ at $4 \mathrm{C}$, and the supernatants were used to assay cAMP by a competitive proteinbinding assay (67) using $4.5 \mathrm{nM}\left[8^{-}{ }^{3} \mathrm{H}\right] \mathrm{CAMP}$ (Amersham), as a tracer. The protein-bound $\left[8-{ }^{3} \mathrm{H}\right] \mathrm{CAMP}$ in the supernatant was measured by liquid scintillation counting using CytoScint (ICN), and a linear standard curve was performed in each assay. The assays were performed with duplicate samples, and the means were used for all further calculations. The percentage of the maximum cAMP accumulated for each data point was calculated using the cAMP accumulated in cells expressing the wild-type receptor, and treated with $1 \mu \mathrm{M}$ hormone, as $100 \%$. The dose-response curves were fit to a sigmoidal dose-response equation, and $\mathrm{ED}_{50}$ values were determined using the program GraphPad Prism (GraphPad Software Inc.).

\section{Acknowledgments}

We thank Dr. Shigekazu Nagata (Osaka Bioscience Institute) for the cDNA clones for the VIP and secretin receptors, Dr. Bernard Moss (NIH, Bethesda, MD) for the use of the Vaccinia-T7 polymerase system, Dr. Robert Lamb (Northwestern University, Evanston, IL) for the monoclonal antibody against the HA epitope, Ken Wu for technical assistance, Katherine Lee for participating in the generation of the HA-tagged truncation constructs, and Drs. Daniel Linzer and Teresa Miller for comments on the manuscript. 
Received October 13, 1997. Revision received and accepted January 15, 1998.

Address requests for reprints to: Kelly E. Mayo, Department of Biochemistry, Molecular Biology and Cell Biology, Northwestern University, Evanston, Illinois 60208. E-mail: k-mayo@nwu.edu.

This work was supported by NIH Grant DK-48071 (to K.E.M.).

\section{REFERENCES}

1. Frohman LA, Jansson JO 1986 Growth hormone-releasing hormone. Endocr Rev 7:223-253

2. Gelato MC, Merriam GR 1986 Growth hormone releasing hormone. Annu Rev Physiol 48:569-591

3. Mayo KE 1992 Molecular cloning and expression of a pituitary-specific receptor for growth hormone-releasing hormone. Mol Endocrinol 6:1734-1744

4. Lin C, Lin SC, Chang CP, Rosenfeld MG 1992 Pit-1dependent expression of the receptor for growth hormone releasing factor mediates pituitary cell growth. Nature 360:765-768

5. Gaylinn BD, Harrison JK, Zysk JR, Lyons CE, Lynch KR, Thorner MO 1993 Molecular cloning and expression of a human anterior pituitary receptor for growth hormonereleasing hormone. Mol Endocrinol 7:77-84

6. Hsiung HM, Smith DP, Zhang XY, Bennett T, Rosteck PJ, Lai MH 1993 Structure and functional expression of a complementary DNA for porcine growth hormone-releasing hormone receptor. Neuropeptides 25:1-10

7. Godfrey P, Rahal JO, Beamer WG, Copeland NG, Jenkins NA, Mayo KE $1993 \mathrm{GHRH}$ receptor of little mice contains a missense mutation in the extracellular domain that disrupts receptor function. Nat Genet 4:227-232

8. Lin SC, Lin CR, Gukovsky I, Lusis AJ, Sawchenko PE, Rosenfeld MG 1993 Molecular basis of the little mouse phenotype and implications for cell type-specific growth. Nature 364:208-213

9. Wajnrajch MP, Gertner JM, Harbison MD, Chua Jr SC, Leibel RL 1996 Nonsense mutation in the human growth hormone-releasing hormone receptor causes growth failure analogous to the little (lit) mouse. Nat Genet 12:88-90

10. Maheshwari I, Silverman BL, Dupuis J, Baumann G, Dwarfism of Sindh: a novel form of familial isolated $\mathrm{GH}$ deficiency linked to the locus for the $\mathrm{GH}$ releasing hormone receptor. Program of the 10th International Congress of Endocrinology, San Francisco, CA, 1996, p 709 (Abstract)

11. Tang J, Lagace G, Castagne J, Collu R 1995 Identification of human growth hormone-releasing hormone receptor splicing variants. J Clin Endocrinol Metab 80:2381-2387

12. Hashimoto K, Koga M, Motomura T, Kasayama S, Kouhara H, Ohnishi T, Arita N, Hayakawa T, Sato B, Kishimoto T 1995 Identification of alternatively spliced messenger ribonucleic acid encoding truncated growth hormone-releasing hormone receptor in human pituitary adenomas. J Clin Endocrinol Metab 80:2933-2939

13. Kolakowski LF, Zhuang J 1997 G Protein-Coupled Receptor Family B. In: The G protein-Coupled Receptor DataBase, World-Wide-Web Site. URL: http://www. gcrdb.uthscsa.edu/FBintro.html

14. Ishihara $T$, Nakamura S, Kaziro $Y$, Takahashi T, Takahashi K, Nagata S 1991 Molecular cloning and expression of a cDNA encoding the secretin receptor. EMBO J 10:1635-1641

15. Ishihara T, Shigemoto R, Mori K, Takahashi K, Nagata S 1992 Functional expression and tissue distribution of a novel receptor for vasoactive intestinal polypeptide. Neuron 8:811-819
16. Pisegna JR, Wank SA 1993 Molecular cloning and functional expression of the pituitary adenylate cyclase-activating polypeptide type I receptor. Proc Natl Acad Sci USA 90:6345-6349

17. Jelinek LJ, Lok S, Rosenberg GB, Smith RA, Grant FJ, Biggs S, Bensch PA, Kuijper JL, Sheppard PO, Sprecher CA, O'Hara PJ, Foster J, Walker KM, Chen LHJ, McKernan PA, Kindsvogel W 1993 Expression cloning and signaling properties of the rat glucagon receptor. Science 259:1614-1616

18. Thorens B 1992 Expression cloning of the pancreatic beta cell receptor for the gluco-incretin hormone glucagon-like peptide 1. Proc Natl Acad Sci USA 89:86418645

19. Usdin TB, Mezey E, Button DC, Brownstein MJ, Bonner TI 1993 Gastric inhibitory polypeptide receptor, a member of the secretin-vasoactive intestinal peptide receptor family, is widely distributed in peripheral organs and the brain. Endocrinology 133:2861-2870

20. Juppner $H$, Abou-Samra A, Freeman $M$, Kong XF, Schipani E, Richards J, Kolakowski Jr LF, Hock J, Potts Jr JT, Kronenberg HM, Segre GV 1991 A G protein-linked receptor for parathyroid hormone and parathyroid hormone-related peptide. Science 254:1024-1026

21. Abou-Samra A, Juppner H, Force T, Freeman MW, Kong XF, Schipani E, Urena P, Richards J, Bonventre JV, Potts Jr JT, Kronenberg HM, Segre GV 1992 Expression cloning of a common receptor for parathyroid hormone and parathyroid hormone-related peptide from rat osteoblast-like cells: a single receptor stimulates intracellular accumulation of both cAMP and inositol trisphosphates and increases intracellular free calcium. Proc Natl Acad Sci USA 89:2732-2736

22. Chen R, Lewis KA, Perrin MH, Vale WW 1993 Expression cloning of a human corticotropin-releasing-factor receptor. Proc Natl Acad Sci USA 90:8967-8971

23. Lin HY, Harris TL, Flannery MS, Aruffo A, Kaji EH, Gorn A, Kolakowski LJ, Lodish HF, Goldring SR 1991 Expression cloning of an adenylate cyclase-coupled calcitonin receptor. Science 254:1022-1024

24. Segre GV, Goldring SR 1993 Receptors for secretin, calcitonin, parathyroid hormone (PTH)/PTH-related peptide, vasoactive intestinal peptide, glucagon-like peptide 1 , growth hormone-releasing hormone and glucagon belong to a newly discovered G-protein-linked receptor family. Trends Endocrinol Metab 4:309-314

25. Gaudin P, Couvineau A, Maoret JJ, Rouyer FC, Laburthe M 1995 Mutational analysis of cysteine residues within the extracellular domains of the human vasoactive intestinal peptide (VIP) 1 receptor identifies seven mutants that are defective in VIP binding. Biochem Biophys Res Commun 211:901-908

26. Gaylinn BD, Lyons CEJ, Mayo KE, Thorner MO, The little mouse GHRH receptor mutation (D60->G) prevents GHRH binding. Program of the 76th Annual Meeting of the Endocrine Society, Anaheim, CA, 1994, p 367 (Abstract)

27. Couvineau A, Gaudin P, Maoret JJ, Rouyer FC, Nicole P, Laburthe M 1995 Highly conserved aspartate 68, tryptophane 73 and glycine 109 in the $\mathrm{N}$-terminal extracellular domain of the human VIP receptor are essential for its ability to bind VIP. Biochem Biophys Res Commun 206:246-252

28. Carruthers CJ, Unson CG, Kim HN, Sakmar TP 1994 Synthesis and expression of a gene for the rat glucagon receptor. Replacement of an aspartic acid in the extracellular domain prevents glucagon binding. J Biol Chem 269:29321-29328

29. Laburthe M, Couvineau A, Gaudin P, Maoret JJ, RouyerFessard C, Nicole P 1996 Receptors for VIP, PACAP, secretin, GRF, glucagon, GLP-1, and other members of their new family of $G$ protein-linked receptors: structure- 
function relationship with special reference to the human VIP-1 receptor. Ann NY Acad Sci 805:94-109

30. Momany FA, Bowers CY 1996 Speculations on the mechanism of hormone-receptor interactions of the secretin/glucagon family of polypeptide hormones derived from computational structural studies. Ann NY Acad Sci 805:172-181

31. Wess J 1993 Mutational analysis of muscarinic acetylcholine receptors: structural basis of ligand/receptor/G protein interactions. Life Sci 53:1447-1463

32. Kobilka BK, Kobilka TS, Daniel K, Regan JW, Caron MG, Lefkowitz RJ 1988 Chimeric alpha 2-, beta 2-adrenergic receptors: delineation of domains involved in effector coupling and ligand binding specificity. Science 240:1310-1316

33. Combarnous $Y 1992$ Molecular basis of the specificity of binding of glycoprotein hormones to their receptors. Endocr Rev 13:670-691

34. Fong TM, Huang RR, Yu H, Strader CD 1993 Mapping the ligand binding site of the NK-1 receptor. Regul Pept 46:43-48

35. Fukuda K, Terasako K, Kato S, Mori K 1995 Identification of the amino acid residues involved in selective agonist binding in the first extracellular loop of the delta- and mu-opioid receptors. FEBS Lett 373:177-181

36. Hunyady L, Balla T, Catt KJ 1996 The ligand binding site of the angiotensin AT1 receptor. Trends Pharmacol Sci 17:135-140

37. Wilmen A, Goke B, Goke R 1996 The isolated N-terminal extracellular domain of the glucagon-like peptide-1 (GLP)-1 receptor has intrinsic binding activity. FEBS Lett 398:43-47

38. Holtmann MH, Hadac EM, Miller LJ 1995 Critical contributions of amino-terminal extracellular domains in agonist binding and activation of secretin and vasoactive intestinal polypeptide receptors. Studies of chimeric receptors. J Biol Chem 270:14394-14398

39. Vilardaga JP, De NP, Di PE, Bollen A, Waelbroeck M, Robberecht P 1995 Properties of chimeric secretin and VIP receptor proteins indicate the importance of the $\mathrm{N}$ terminal domain for ligand discrimination. Biochem Biophys Res Commun 211:885-891

40. Cao YJ, Gimpl G, Fahrenholz F 1995 The amino-terminal fragment of the adenylate cyclase activating polypeptide (PACAP) receptor functions as a high affinity PACAP binding domain. Biochem Biophys Res Commun 212:673-680

41. Vilardaga JP, di Paolo $E$, de Neef $P$, Waelbroeck $M$, Bollen A, Robberecht P 1996 Lysine 173 residue within the first exoloop of rat secretin receptor is involved in carboxylate moiety recognition of Asp 3 in secretin. Biochemistry 218:842-846

42. Holtmann MH, Ganguli S, Hadac EM, Dolu V, Miller LJ 1996 Multiple extracellular loop domains contribute critical determinants for agonist binding and activation of the secretin receptor. J Biol Chem 271:14944-14949

43. Du K, Nicole P, Couvineau A, Laburthe M 1997 Aspartate 196 in the first extracellular loop of the human VIP1 receptor is essential for VIP binding and VIP-stimulated cAMP production. Biochem Biophys Res Commun 230:289-292

44. Hashimoto H, Ogawa N, Hagihara N, Yamamoto K, Imanishi K, Nogi H, Nishino A, Fujita T, Matsuda T, Nagata S, Baba A 1997 Vasoactive intestinal polypeptide and pituitary adenylate cyclase-activating polypeptide receptor chimeras reveal domains that determine specificity of vasoactive intestinal polypeptide binding and activation. Mol Pharmacol 52:128-135

45. Turner PR, Bambino T, Nissenson RA 1996 A putative selectivity filter in the G-protein-coupled receptors for parathyroid hormone and secretin. $\mathrm{J}$ Biol Chem 271:9205-9208

46. Buggy JJ, Livingston JN, Rabin DU, Yoo-Warren H 1995
Glucagon.glucagon-like peptide I receptor chimeras reveal domains that determine specificity of glucagon binding. J Biol Chem 270:7474-7478

47. Stroop SD, Kuestner RE, Serwold TF, Chen L, Moore EE 1995 Chimeric human calcitonin and glucagon receptors reveal two dissociable calcitonin interaction sites. Biochemistry 34:1050-1057

48. Unson CG, Cypess AM, Kim HN, Goldsmith PK, Carruthers CJ, Merrifield RB, Sakmar TP 1995 Characterization of deletion and truncation mutants of the rat glucagon receptor. Seven transmembrane segments are necessary for receptor transport to the plasma membrane and glucagon binding. J Biol Chem 270:27720-27727

49. Juppner H, Schipani E, Bringhurst FR, McClure I, Keutmann HT, Potts Jr JT, Kronenberg HM, Abou-Samra A, Segre GV, Gardella TJ 1994 The extracellular aminoterminal region of the parathyroid hormone (PTH)/PTHrelated peptide receptor determines the binding affinity for carboxyl-terminal fragments of PTH-(1-34). Endocrinology 134:879-884

50. Lee C, Luck MD, Juppner H, Potts Jr JT, Kronenberg HM, Gardella TJ 1995 Homolog-scanning mutagenesis of the parathyroid hormone $(\mathrm{PTH})$ receptor reveals PTH(1-34) binding determinants in the third extracellular loop. Mol Endocrinol 9:1269-1278

51. Gelling RW, Wheeler MB, Xue J, Gyomorey S, Nian C, Pederson RA, McIntosh CHS 1997 Localization of the domains involved in ligand binding and activaton of the glucose-dependent insulinotropic polypeptide receptor. Endocrinology 138:2640-2643

52. Liaw CW, Grigoriadis DE, Lovenberg TW, De Souza EB, Maki RA 1997 Localization of ligand-binding domains of human corticotropin-releasing factor receptor: a chimeric receptor approach. Mol Endocrinol 11:980-987

53. Mayo KE, Godfrey PA, Suhr ST, Kulik DJ, Rahal JO 1995 Growth hormone-releasing hormone: synthesis and signaling. Recent Prog Horm Res 50:35-73

54. Maggio R, Vogel Z, Wess J 1993 Reconstitution of functional muscarinic receptors by co-expression of aminoand carboxyl-terminal receptor fragments. FEBS Lett 319:195-200

55. Remy JJ, Bozon V, Couture L, Goxe B, Salesse R, Garnier J 1993 Reconstitution of a high-affinity functional lutropin receptor by coexpression of its extracellular and membrane domains. Biochem Biophys Res Commun 193:1023-1030

56. Xie YB, Wang H, Segaloff DL 1990 Extracellular domain of lutropin/choriogonadotropin receptor expressed in transfected cells binds choriogonadotropin with high affinity. J Biol Chem 265:21411-21414

57. Ji IH, Ji TH 1991 Human choriogonadotropin binds to a lutropin receptor with essentially no $\mathrm{N}$-terminal extension and stimulates cAMP synthesis. J Biol Chem 266:13076-13079

58. Moyle WR, Bernard MP, Myers RV, Marko OM, Strader CD 1991 Leutropin/beta-adrenergic receptor chimeras bind choriogonadotropin and adrenergic ligands but are not expressed at the cell surface. J Biol Chem 266:10807-10812

59. Usdin TB, Bonner TI, Mezey E 1994 Two receptors for vasoactive intestinal polypeptide with similar specificity and complementary distributions. Endocrinology 135:2662-2680

60. Unson CG, Cypess AM, Wu CR, Goldsmith PK, Merrifield RB, Sakmar TP 1996 Antibodies against specific extracellular epitopes of the glucagon receptor block glucagon binding. Proc Natl Acad Sci USA 93:310-315

61. Kolodziej PA, Young RA 1991 Epitope tagging and protein surveillance. Methods Enzymol 194:508-519

62. Hopp TP, Prickett KS, Price V, Libby RT, March CJ, Ceretti P, Urdal DL, Conlon PJ 1988 A short polypeptide marker sequence useful for recombinant protein identification and purification. Biotechnology 6:1205-1210 
63. Horton RM, Hunt HD, Ho SN, Pullen JK, Pease LR 1989 Engineering hybrid genes without the use of restriction enzymes: gene splicing by overlap extension. Gene 77:61-68

64. Deng WP, Nickoloff JA 1992 Site-directed mutagenesis of virtually any plasmid by eliminating a unique site. Anal Biochem 200:81-88

65. Fuerst TR, Earl PL, Moss B 1987 Use of a hybrid vaccinia virus-T7 RNA polymerase system for expression of target genes. Mol Cell Biol 7:2538-2544

66. Campbell MJ 1995 Lipofection reagents prepared by a simple ethanol injection technique. Biotechniques 18:1027-1032

67. Tovey KC, Oldham KG, Whelan JAM 1974 A simple direct assay for cyclic AMP in plasma and other biological samples using an improved competitive protein binding technique. Clin Chim Acta 56:221-234

\section{Hormones and the Heart}

Naples, Italy, September 24-26, 1998

Conveners: Gaetano Lombardi (Naples, I) and Luigi Saccà (Naples, I)

Participants: E. Ambrosioni, Bologna, I; M. Andreoli, Rome, I; S. Anker, London, UK; A. Bellastella, Naples, I; B.-Å. Bengtsson, Gothenberg, S; A. Boccanelli, Rome, I; R. H. Böger, Hanover, D.; L. E. Braverman, Worcester, MA; M. Chiariello, Naples, I; J. S. Christiansen, Aarhus, DK; W. H. Dillmann, La Jolla, CA; P. S. Douglas, Boston, MA; G. Faglia, Milan, I; G. Fenzi, Naples, I; E. Ghigo, Turin, I; G. Giordano, Genoa, I; A. Giustina, Brescia, I; Å Hjalmarson, Gothenberg, S; I. Klein, New York, NY; G. Johannsson, Gothenberg, S; D. G. Johnston, London, UK; P. W. Ladenson, Baltimore, MD; G. D. Lopaschuk, Edmonton, Alberta, CND; M. Metra, Brescia, I; K. Ojamaa, Manhasset, NY; A. Pinchera, Pisa, I; E. C. Ridgway, Denver, CO; B. Trimarco, Naples, I; R. Vigneri, Catania, I; L. Wartofsky, Washington, DC.

Topics: Insulin regulation of myocardial metabolism and performance; Biochemical basis of thyroid hormone action; Thyroid hormone and cardiovascular physiology; Overt and subclinical thyrotoxicosis and hypothyroid diseases: clinical studies and management; Effects of thyroid hormone on cardiovascular performance during non-thyroidal illness; GH/IGF-1 axis in heart failure and in cachexia: clinical implications, GH/IGF-1 in experimental heart failure; $\mathrm{GH}$ and heart failure; GH/IGF-1 and endothelial function; $\mathrm{GH}$ and metabolic risk factors; GH and premature atherosclerosis; Aldosterone in heart failure; ACE inhibitors in heart failure; Angiotensin II receptor blockade in heart failure; Beta-blockers in heart failure.

This Meeting will give a unique opportunity to gain insights into the physiological relevance of a number of hormones in relation to the cardiovascular system and to learn about their potential role in the cure of heart failure. It will be of prime interest to all those conducting basic and clinical research in cardiology, endocrinology, angiology and metabolic diseases.

Deadline for abstract submission: 15 June 1998

Contact: Jean Gilder Congressi srl. Tel. +39 81 5463779; Fax +39 81 5463781; e-mail: jgcon@tin.it

Visit our web site for information about the meeting and online registration: http://www. jgcon.com 